\title{
Unraveling the neuroprotective effect of Tinospora cordifolia in Parkinsonian mouse model through proteomics Approach.
}

Hareram Birla

Banaras Hindu University

Chetan Keswani

Banaras Hindu University

Saumitra Sen Singh

Banaras Hindu University

Walia Zahra

Banaras Hindu University

Hagera Dilnashin

Banaras Hindu University

Aaina Singh Rathore

Banaras Hindu University

Richa Singh

Banaras Hindu University

Monika Rajput

Banaras Hindu University

Surya Pratap Singh ( $\nabla$ suryasinghbhu16@gmail.com )

Banaras Hindu University https://orcid.org/0000-0002-0369-4699

\section{Research Article}

Keywords: Parkinson's disease, Neuroprotection, Tinospora cordifolia, Proteomics, Label free quantification

Posted Date: March 22nd, 2021

DOI: https://doi.org/10.21203/rs.3.rs-151144/v2

License: (1) (1) This work is licensed under a Creative Commons Attribution 4.0 International License.

Read Full License 
Version of Record: A version of this preprint was published at ACS Chemical Neuroscience on November 8th, 2021. See the published version at https://doi.org/10.1021/acschemneuro.1c00481. 


\section{Abstract}

Stress-induced dopaminergic (DAergic) neuronal death in the midbrain region is the primary cause of Parkinson's disease (PD). From the discovery of L-dopa, multiple drugs were discovered to improve lifestyle of PD patients, but they failed due to their multiple side effects. Tinospora cordifolia (Tc), a medicinal herb has been used in traditional medicines to treat neurodegenerative diseases. In our previous study, the neuroprotective role of Tc against MPTP intoxicated Parkinsonian mice was reported. Here, we further explore the neuroprotective molecular mechanisms of Tc in Rotenone (ROT) intoxicated mouse model through proteomics approach. Mice were pretreated with Tc extract by oral administration, followed by ROT-intoxication. Behavioral tests were performed to check motor functions of mice. Protein was isolated, and label free quantification (LFQ) was carried out to identify differentially expressed protein (DEPs) in control vs. PD and PD vs. treatment group. In this study, we report 800 DEPs in control vs. PD and 133 in PD vs. Treatment group. In silico tools clearly demonstrate significant enrichment of biochemical and molecular pathways with DEPs which are known to be important for PD progression including mitochondrial gene expression, PD pathways, TGF- $\beta$ signaling, Alzheimer's disease etc. This results were further validated by qRT-PCR and found that the expression of target gene were identical to the proteomics data. This study provides a novel insight for the disease progression as well new therapeutic tagets. More importantly, it demonstrates that Tc exerts the therapeutic effects through the regulation of multiple pathways to protect DAergic neurons.

\section{Introduction}

Global burden of neurological diseases has doubled during 1990 to 2015. Among these, Parkinson's disease (PD) growth was fastest in prevalence and death [1,2]. PD is the second most prevalent neurodegenerative disease with progressive and continuous death of dopaminergic (DAergic) neurons in the grey matter, following to the decrease in Dopamine (DA) concentration in the striatal region [3-5]. The consequential DA deficiency leads to impaired motor function including tremors, rigidity, bradykinesia and akinesia [6]. The centerpiece of PD management is to execute symptomatic treatment with L-dopa but due to its various side effect like nausea, hallucination, dyskinesia, lower blood pressure, confusion, loss of appetite it has limited efficacy [7].

Lately, scientists have been recommending environmental factors (viz. exposure to pesticides) as the contributory factor to PD onset and progression. Recent studies revealed that Rotenone (ROT), a pesticide which is also an inhibitor of mitochondrial complex-l; when administrated consistently, recapitulated PD's features like reactive oxygen species (ROS) generation, degeneration of the nigrostriatal DAergic system etc. [8-10]. As PD advances, the death of DAergic neurons surges and these neurons don't have potency to regenerate. After investigating the available therapeutics used for the treatment of PD, it seems that they only provide symptomatic relief with serious side effects and affects the quality of life. Therefore, the development of effective therapeutic agents having the ability to protect the neurons and to diminish side effects are much needed. Scientists have been working on natural alternatives which provide efficient neuroprotection, subsequent impending basic pathological conditions [11]. The literature study 
revealed that several medicinal plants including Mucuna pruriens, Bacopa monnieri, Withania somnifera, Tinospora cordifolia (Tc) and their active constituents have neuroprotective effects against neuronal cell death in PD [12-16].

Various studies reported that Tc possesses neuroprotective activity and its co-administration with L-Dopa reduces intra neuronal oxidative stress [17]. Kosaraju et al. (2014) in 6-OHDA model of PD reported that, Tc exhibits significant neuroprotective effects as well as improved levels of dopamine and reduces iron toxicity in rat brain [18]. In our previous study, we demonstrated that Tc has neuroprotective as well as anti-neuroinflammatory activity in mice brain mainly due to inhibition of NF-kB and other proinflammatory molecule such as TNF-a, IL-12, IL-1 3 , and restoration of Tyrosine hydroxylase levels, a key enzyme in the synthesis of DA [19]. Sharma et al. (2020) reported that butanolic extract of Tc has reversed the glutamate-induced neurodegeneration in hippocampus region of rat brain [20].

Proteomics approach accounts for analysis of total protein content at different levels of organization (cell, tissue and organism) at different development stages [21]. Nowadays proteomic approach has ignited much attention in different facets of genomics and cellular behavior. With the help of proteomics, we can identify novel molecular pathways involved in the progression of PD. By targeting these pathways we can conclude early disease diagnosis, prognosis and to monitor the stage of disease development and recognition of advanced drug targets can be achieved [22-25]. Further we can also improve the reproducibility and performance of the available treatment strategies. Therefore, this study was executed to fulfil the gap between PD pathogenesis and treatment strategies [26]. Our study mainly focused on identification of new molecular targets in PD and the mechanism of action through which Tc reverses the disease progression. In the present study, we used label-free quantification (LFQ) based on LC-MS/MS, due to its high sensitivity, reproducibility and reliability to study the protein expression patterns in the nigrostriatal region of midbrain of mice [27]. Using this method, quantification of the differentially expressed proteins (DEPs) of control vs. Parkinsonian group, and Parkinsonian vs. Tc group was performed. Our results revealed that the Tc treatment improves the behavioral abnormalities in PD mice and in label free proteome analysis, we tried to report multiple proteins in both groups, which were differentially expressed. From these results, we have selected 21 proteins whose expression were significantly modulated in PD as well as treatment group and performed bioinformatics analysis, gene ontology (GO), functional pathway enrichment analysis along with protein-protein interaction (PPI) network and gene-gene interaction, to investigate the correlation with previously reported protein and gene prominent pathway influenced by Tc for neuroprotective activity. These results may assist to figure out the new therapeutic approaches for prevention and treatment of PD.

\section{Experimental Procedure}

\section{Plant Extract Preparation}

Tc stem was procured from Botanical garden, Institute of Science, Banaras Hindu University, Varanasi, India in month of January 2019. Tc stems were dried for 7-10 days in shade and pulverized with the help 
of an electric grinder. The dried sample was extracted with ethanol and water solvent at a ratio of 70:30 (200 gm powder into $1000 \mathrm{~mL}$ ) at $40{ }^{\circ} \mathrm{C}$ for $16 \mathrm{~h}$ in Soxhlet apparatus. Consequently, the plant extract was filtered through $0.45 \mu \mathrm{m}$ filter and the residue was concentrated under reduced pressure using rotary vacuum evaporator. The plant extract are expressed in terms of dry weight [28-30].

\section{Ethical Statement}

The care and maintenance of the experimental animals was carried out in strict accordance with the Animal Ethics procedure and guidelines of the Institutional Animal Ethical Committee of the Banaras Hindu University, Varanasi, India (Ref no. BHU/DoZ/IAEC/2018-19/032). All the efforts were made to ease suffering of mice used in the study.

For conducting the experiment male Swiss albino mice $(25 \pm 5 \mathrm{~g})$ was obtained from the animal facility atInstitute of Medical Science, Banaras HinduUniversity, Varanasi (India). The mice were housed in cleanpolypropylene cages with constant light-dark cycles (12/12 h)prior to the experiment. Until the dosing was completed, mice were supplied with water and standard diet pellets ad libitum. The experimental protocol was established in accordance with the guidelines of the Animal Ethics Committee,Banaras Hindu University, Varanasi, India.

\section{Animal Dosing}

Animals were randomly assigned into three groups: Control (vehicle group), Rotenone ( $2 \mathrm{mg} / \mathrm{kg}$ body wt. per day) subcutaneously for 35 days and Rotenone + Tc (200 mg/kg body wt. per day) orallyadministered for 7 days, then concurrent administration of Tc (21 days) and ROT-intoxication (35 days) were done similar to that Rotenone group ( $n=8$ /group). In accordance with our previous study, dosing was administered with minor changes [19,31]. Upon completion of the dosing, behavioral analysis was carried out, and the mice were sacrificed to isolate the brains for the proteome analysis. All the experiments were carried out in triplicate.

\section{Behavioral Analysis}

To determine the effect of ROT-intoxication on the motor activity in Parkinsonian mouse model, behavioral parameters including the catalepsy test, rotarod test, pole test, and foot-print assay were performed.

\section{Catalepsy Test}

Stiffness in the muscles of mice can be estimated by placing the forelimbs of mice on an elevated bar and the hind limbs on the ground. Catalepsy intensity was measured by recording the time when the mice moves their hind limbs from a wooden platform $(3 \mathrm{~cm}$ in height) to correct their posture. The was recoded in second and the test was discontinued when the time exceeded $180 \mathrm{sec}$ [32].

\section{Pole Test}


Initially, for two consecutive days, the mice were trained. The performance was recorded after the last ROT injection. Mice were placed head-up on the top of a rod $(10 \mathrm{~mm}$ in diameter, $52 \mathrm{~cm}$ in height, with rough surface). T-turn (time taken to orient downward) and T-descend (the time required for the mouse to step down the rod length) were recorded in second and experiment was discontinued after $300 \mathrm{sec}$ [33].

\section{Rotarod Test}

For the rotarod test, each mouse was trained in a rotarod before the experiment for three consecutive days, at a set speed of $15 \mathrm{rpm}$. The time was recorded till the mouse fall from the rotarod and reading were recorded up to $5 \mathrm{~min}$. For each mouse, the test was repeated five times and the mean time was recorded. The difference in fall time observed between the PD group and the Tc-treated group is an indicator of muscle relaxation [34].

\section{Footprint Assay}

In the footprint test, the mice were trained to walk on a white paper for three consecutive days. The length of the stride was calculated by immersing the mouse's forefoot in blank ink and measuring the gap between the steps, from the middle toe (first step) to the heel (second step) on the same side of the body [35]. Foot print assay was conducted thrice for each animal. Stride forepaw length were recorded in $\mathrm{cm}$.

\section{Tissue Collection}

After behavioral tests, mice were sacrificed by cervical dislocation followed by decapitation to ensure minimal pain. The brain of each mouse was isolated and instantly frozen. Later, the brain was dissected under ice cold conditions to isolate the nigrostriatal tissue from the midbrain and was stored at $-80^{\circ} \mathrm{C}$ until the further experiments were performed.

\section{Sample Preparation for LFQ Analysis}

Protein extraction was done following the previous method of Gupta et. al. (2010) with slight modifications [32]. The brain tissue was thawed, and homogenized using the lysis buffer (RIPA, and protease cocktail inhibitor) and incubated for $90 \mathrm{~min}$ on ice. The homogenate was centrifuged at 12,000 rpm at $4{ }^{\circ} \mathrm{C}$ for $20 \mathrm{~min}$, and the supernatant was collected in a fresh eppendorf tube. The proteins were quantified by Bradford assay and expressed in terms of $\mathrm{mg} / \mathrm{ml} / \mathrm{gm}$. tissue [36]. Quantitative assessment of the protein samples was performed by SDS-PAGE.

$100 \mathrm{mg}$ of the protein sample was taken from each group for digestion. The samples were diluted with 50 $\mathrm{mM} \mathrm{NH}_{4} \mathrm{HCO}_{3}$ protein followed by treatment with $100 \mathrm{mM}$ dithiothreitol (DTT) at $95^{\circ} \mathrm{C}$ for $1 \mathrm{~h} .250 \mathrm{mM}$ iodoacetamide (IDA) was added to the RT in dark and incubated for $45 \mathrm{~min}$. The samples were then digested with Trypsin (Trypsin gold promega, USA) and incubated overnight at RT. The resulting sample was vacuum dried and dissolved in $50 \mu \mathrm{l}$ of $0.1 \%$ formic acid (FA) in water, followed by centrifugation at $10,000 \mathrm{rpm}$ and the supernatant was collected into a separate tube. $10 \mu \mathrm{L}$ injection volume was used on BEH C18 UPLC column for separation of peptides, the mobile phase contained $0.1 \%$ FA in water (buffer A) 
and $0.1 \%$ FA in Acetonitrile (98:2 v/v for 1-30 min, 50:50 v/v for 30-40 min, 20:80 v/v for 40-50 min then $98: 2 \mathrm{v} / \mathrm{v}$ for the next $30 \mathrm{~min}$ ), and the flow rate was set at $0.3 \mathrm{ml} / \mathrm{min}$. The glutamate level was examined at a wavelength of $472 \mathrm{~nm}$, and the concentration was determined using a standard curve. Three runs per sample were carried out for LFQ. The separated peptides on the column were directed to Waters Synapt G2 Q-TOF instrument for MS and MS/MS analysis. The raw data was processed by MassLynx 4.1 WATERS. The individual peptides MS/MS spectra were matched to the database sequence on PLGS software (ProteinLynx Global Server Software Scores each protein based on the significance of the protein being identified based on MS pattern and MS/MS pattern matching for each peptide, as well as the coverage), WATERS for protein identification (Figure 6). The instrument used for acquiring Mass Spec Data was connected with Waters Synapt G2 (QTOF). The instrument parameters used for identification were Peptide Mass Tolerance at MS1 level: 50 ppm and Fragment Mass Tolerance at MS2 level: 100 $\mathrm{ppm}$. During processing of the sample cysteine sites were modified to carbamidomethylated cysteine, and the methionine sites being prone to oxidation, was considered as a variable modification to the mass $[37,38]$.

\section{Bioinformatics Analysis}

\section{Gene Ontology and Pathway enrichment analysis}

The biological significance of DEGs was investigated using WebGestalt, as it is a free online WEB-based gene set analysis toolkit for functional enrichment analysis in different biological levels. In GO and PATHWAY enrichment analysis, we obtained more valuable knowledge about cellular, molecular and biological processes. A $p$-value $<0.05$ was considered a significant enrichment [39].

\section{Protein-Protein Interaction Networks Analysis}

Search tool for the retrieval of interacting genes database (STRING) is a database and web resource for forecasting PPI networks. To investigate the relationship between DEGs, the STRING database was used. Our active interaction source of data was text mining, experiments, database, co-expression, gene fusion and co-occurrence. Minimum required score is set 0.7 (higher confidence). By analyzing the predicted interaction networks, we can propose new directions for future experimental research and come up with cross-species forecasts for systematic interconnecting mapping [40].

\section{Investigation through KEGG Mapper tool and Genemania}

KEGG mapper tool is used for cellular or biological interpretation of large-scale data sets like genome or meta genome sequence [41]. It comprises of three different databases, Brite, Pathway and Module which, further contains experimental information from the already published literature and represented in the form of these three different pathways. Bioinformatics tools such as Genemania was used for imaging and visualizing the different interacting networks between different genes $[42,43]$. The interaction between genes may be physical, correlation, colocalize and genetic interactions. It also provides the information about the interaction with unknown genes from already published literature. 


\section{Quantitative Real-Time Reverse Transcriptase Polymerase Chain Reaction (qRT-PCR)}

For gene expression analysis, total RNA was isolated from SNpc region of different groups of mice according to manufacturer's protocol (Invitrogen, Carlsbad, CA). After isolation, RNA quantification and purity was estimated on A260/A280 using Nanodrop 1000. cDNA was prepared by reverse transcription process and for this $2 \mu \mathrm{g}$ total RNA (kept equal for each amplification), 20U M-MLV reverse transcriptase (Fermantas, Germany), 20 mM dNTPs (New England Biolabs, USA), $1 \times$ RT buffer, 20 U RNasin (Fermentas, Germany), $100 \mathrm{ng}$ of random hexamers (Fermentas, Germany) and 0.1 M DTT with DEPC treated water. Gene expression profile analysis was performed on ABI7500 Fast system. PCR reaction was carried out as stated in previously reported studies with few modifications [19]. The real time mix includes $5 \mu \mathrm{l}$ of SYBER green master mix (Applied Biosystem), $0.5 \mu \mathrm{l}$ each of forward primers and reverse primers (dnmt1, Akt1, Tiam1, Tfam, Gpr37, smad7, Grin2a, Kdm3a), $1 \mu$ cDNA, $1 \mu$ l RNase inhibitor and 2 $\mu \mathrm{l}$ nuclease free water. PCR reaction was set up according to the following protocol: initial incubation at $50{ }^{\circ} \mathrm{C}$ for $2 \mathrm{~min}$, denaturation at $95^{\circ} \mathrm{C}$ for $10 \mathrm{~min}$, and 40 cycles at $95^{\circ} \mathrm{C}$ for $15 \mathrm{~s}, 60^{\circ} \mathrm{C}$ for $1 \mathrm{~min}$, and 72 ${ }^{\circ} \mathrm{C}$ for $40 \mathrm{~s}$. The abundance or declines of mRNA were normalized to the geometric average of endogenous control GAPDH for $\Delta \mathrm{Ct}$. The fold change $(\Delta \mathrm{Ct})$ was calculated by $2-\Delta \Delta \mathrm{Ct}$ method and reported as arbitrary unit.

\section{Statistical Analysis.}

Statistical analysis of behavioral data was done by one-way analysis of variance (ANOVA) using the Student-Newman-Keuls test by GraphPad Prism 6.0. For gene expression, we applied Student's t-test to unequal variances in order to find the $p$-value for each gene. The results are expressed as the mean \pm SEM. $p$ values $<0.05$ were considered statistically significant.

\section{Results}

\section{Neurobehavioral Parameters}

After ROT injection, stiffness was observed in mice by catalepsy test. The latency in the ROT group tended to increase over time $(p<0.001)$, and the observed data was significantly different from those in the control group, but Tc-treated mice showed a shorter latency time $(p<0.001)$, instead of the ROTintoxicated group (Figure 1a). In the pole test, ROT-intoxicated mice showed prolonged T-turn in comparison to control group mice $(\mathrm{p}<0.01)$. The T-descend duration in Tc pre-treated mice was significantly reduced $(p<0.01$ ) (Figure $1 b)$. Rotarod test was performed to check the balance, grip, and movement adjustment of the mice. Compared to control, ROT-intoxicated group had significantly reduced retention time $(p<0.001)$ on rotarod, and it was observed that mice lost motor coordination and grip strength. Compared to ROT-intoxicated mice, Tc treatment significantly increased retention time on rotarod $(p<0.01)$ (Figure 1c). Footprint analysis showed differences in average stride length between the control group, ROT group, and Tc-treated group. The stride difference in the ROT-intoxicated group was significantly reduced compared to the control group $(p<0.01)$, whereas the gait disturbance was significantly improved on Tc treatment $(p<0.05)$ (Figure $1 d)$. 


\section{Comparative Protein Profiling Between control vs. PD and PD vs. Treatment Group}

The protein profiling was analyzed through PGLC software (Masslynux 4.1 Water, USA) and compared between control vs. Parkinsonian and Parkinsonian vs. Tc mice group. On the basis of fold change, the significance of differences in protein expression was also categorized. The protein whose fold change value was below $(\leq 0.5)$ were consider downregulated and those protein whose value was greater than 2.0 fold were considered upregulated (Table 1 and Table 2, Figure 3). The label-free LC-MS/MS results demonstrated that control vs. PD group contained 800 DEPs of which 67 were downregulated (Table 1A) and 101 were upregulated (Table 1B). In PD vs. TC group, 133 DEPs were obtained of which 11 (Table 2A) were downregulated and 13 were upregulated (Table 2B). Besides this, some proteins which were significantly expressed in the PD group were normalized by Tc (fold change between (0.5-2.0)) (Supplementary file 1, Figure 2). From this analysis, we identified 21 proteins whose expression was significantly modulated in ROT-intoxicated Parkinsonian group and was efficiently restored with the treatment of Tc. Some prominent upregulated proteins included Short transient receptor potential channel, glutamate receptor inotropic early endosome antigen 1, Serine/threonine-protein phosphatase $2 \mathrm{~A}$, transcription factor $\mathrm{A}$, aryl hydrocarbon receptor nuclear translocator, eukaryotic translation initiation factor 5B, prosaposin receptor GPR37, RAC-alpha serine/threonine-protein kinase and neutrophil cytosol factor 4 (Table 2A). whereas ubiquitin carboxyl-terminal hydrolase, DNA (cytosine-5)-methyltransferase 1 , phosphatidylinositol 3,4,5-trisphosphate 5-phosphatase 2, ribosome-releasing factor 2, phospholipase D1, receptor-type tyrosine-protein phosphatase, centromere protein I, mothers against decapentaplegic homolog 7, lysine-specific demethylase 3A, T-lymphoma invasion and metastasis-inducing protein 1 were the prominently downregulated proteins (Table 2B).

\section{Gene Ontology and Functional Pathway Enrichment Analysis}

To comprehend the potential functions of DEPs in PD, these DEPs were examined. GO analysis (http://www.geneontology.org) of most significant DEPs based on Biological Process (BP), Molecular Function (MF) and Cellular Component (CC) has been shown in (Figure 4, Supplementary file 2 Tables 1 , 2 and 3). This analysis revealed that dopamine metabolic process, catechol-containing compound metabolic process, catecholamine metabolic process, adherens junction assembly, mitochondrial gene expression, phenol-containing compound metabolic process, oligodendrocyte differentiation, adherens junction organization, positive regulation of protein modification by small protein conjugation or removal, response to toxic substance were found to be significantly enriched in BP. Furthermore, NMDA selective glutamate receptor complex, neuron spine, cation channel complex, extrinsic component of plasma membrane, cell-cell junction, cell junction, cell surface, transmembrane transporter complex, ion channel complex, extrinsic component of membrane were significantly enriched in CC. Moreover, TGF- $\beta$ receptor, cytoplasmic mediator activity, ligand-gated ion channel activity involved in regulation of presynaptic membrane potential, $\mathrm{Ca}^{2+}$-transmembrane transporter activity, $\beta$-catenin binding, heat shock protein binding, NMDA glutamate receptor activity, $\delta$-catenin binding, $\mathrm{Ca}^{2+}$ channel activity was significantly enriched in MF. The criteria for $p$-values $<0.05$ was considered significant for enriched GO analysis. To investigate the enriched pathways associated with PD was performed using software Webgestalt 
(http://www.webgestalt.org). In this study we analyze various significant pathways through Wikipathway (https://www.wikipathways.org/index.php /WikiPathways) which has been shown in (Table 3). Enriched pathway analysis demonstrated that DEPs were highly involved in PD Pathway (Gpr37), Alzheimer's disease pathway, hypothetical network for drug addiction (Grin2a), mitochondrial gene expression (Tfam), lung fibrosis, TGF- $\beta$ signaling pathway, Hfe effect on hepcidin production, ESC pluripotency (Smad7) and chemokine signaling pathway (Tiam 1).

\section{In silico Analysis through PPI Network}

PPIs play a crucial role in understanding the molecular function of DEPs, responsible for the PD onset. As the outcome, hub genes like AKT1, PARK2, MTOR, TFAM, PINK1, TH, SNCA, PID1, PARK7, LRRK2 and App were found with the highest degrees of connection in the network (Figure 5A). In a constructed network, DEPs connected to each other, generally have analogous functions and can be considered as the functional genes. Gene-gene interaction network was constructed to investigate the interaction of significant proteins in the network (Figure 5B).

\section{The qRT-PCR further confirmed the neuroprotective role of Tc by Regulating Various Signaling Pathways}

Quantitative PCR were performed to check the expression various gene involved PD pathogenesis (SMAD7, GPR37, KDM3A, DNMT1, TIAM1, TFAM, AKT1, and GRIN2A). This result confirmed the potential role of Tc in regulating pathogenesis of PD in mice model through modulation multiple gene. The qRTPCR was done (Figure 7) with GAPDH, taken as endogenous mRNA control. The qRT-PCR revealed upregulation of SMAD7 (1.97 fold), KDM3A (1.97fold), DNMT1 (2.93 fold), and TIAM1 (2.90 fold) in ROTintoxicated mice with respect to healthy control, while TFAM ( 0.33 fold), AKT1 ( 0.37 fold), GPR37 ( 0.46 fold) and Grin2a ( 0.23 fold) were found to be down-regulated. After treatment with TC, there was a significant decrease in SMAD7 ( 0.17 fold), KDM3A ( 0.27 fold), DNMT1 ( 0.32 fold), and TIAM1 ( 0.62 fold) and an increment was found in the level of TFAM (1.10 fold), AKT1 (1.39 fold), GPR37 (1.55 folds) and GRIN2A (1.73 fold) as shown in (Figure 7$)$, displaying the fact that Tc has got significant potential role in PD pathogenesis via regulating different signaling pathways.

\section{Discussion}

Discovery of L-dopa was a major step forward in the treatment of PD, but its major drawback was the generation of various side effects. In addition, many combinational drugs were reported to reduce the side effects, but the success rate was very low [44]. Besides, the researchers also focused on other molecular targets as well as the alternative treatment options to improve the lifestyle of PD patients. PD attributed by mitochondrial dysfunctions, impairment of protein degradation, oxidative stress and death of DAergic neurons in SN, but the continuous progression of molecular events leading to cell death remains unclear [45]. Prior to designing any preventive intervention, in-depth knowledge of the molecular mechanisms underlying neurodegeneration in PD is required. 
ROT, is a well-known pesticide acting selectively on mitochondrial complex l, causing its inhibition like $\mathrm{MPP}^{+}$. A growing body of proofs suggest that the insecticide model offers more advantages over different experimental models as it will effectively mimic the behavioral and neuropathological symptoms of the illness through the selective degeneration of DAergic neurons $[46,47]$.

PD have various motor (tremor, slowness of movement, rigidity, falls and dizziness, freezing, postural imbalance) [48] and non-motor symptoms (pain, low blood pressure, fatigue, restless legs, swallowing and saliva control, sleep, skin and sweating, bowel and bladder problems) [49]. Various studies reported that non motor symptoms generally develop at the initial stage of PD progression so that it is not able to differentiate PD patients from others. Zahra et al. (2020) reported the characteristic motor impairment in ROT-intoxicated Parkinsonian mice [31]. To check the behavioral deficit in mice, we performed various behavioral tests such as catalepsy, rotarod, pole, and footprint, which highlighted severe motor abnormalities in ROT-intoxicated PD mouse model [42-45] (Figure 1). Indistinguishable co-ordinates and deterioration of motor skills were also observed in our result due to ROT toxicity, whereas the behavioral tests demonstrates that Tc improves the neurobehavioral shortfall as compared with previous studies [50].

Various medicinal herbs are used for therapeutic functions since ancient times in India, China, and other Asian countries. Medicinal plants are used to treat various neurodegerative diseases [51] and showed very promising results with minimal side effects. Herbs like Bacopa monnieri, Withania somnifera, Mucuna pruriens, Tc, are tested for its therapeutic potential against neurodegenerative diseases via redox balancing and immunomodulation activities [18,52,53]. In our previous study, we reported that Tc has neuroprotective role via suppressing oxidative stress as well as neuroinflammation [19].

With the application of proteomic profiling analysis, the quantitative and qualitative analysis of thousands proteins from the tangled mixtures along with the demonstrations of their PTMs could be efficiently performed. Based on our findings, we have identified various new molecules and pathways as alternate treatment approach. Here, we used comparative proteome profiling through LFQ/LC-MS/MS to investigate DEP in nigrostriatal region of mice brain. Out of total 800 DEPs, 101 were upregulated and 76 were downregulated in ROT-intoxicated mice compared to control; whereas, out of total 133 DEPs in Tctreated mice, 13 were upregulated and 11 were downregulated as compared to ROT. Some proteins which are significantly expressed in PD group were reversed by Tc treatment. On the basis of expression and corelation with PD marker proteins, we selected 21 proteins (Table 2A, Table 2B). Further in-silico analysis suggested that some of DEPs (Smad7, Tfam, Grin2a, Gpr37, and Tiam7) play a key role in PD pathogenesis via regulating different signaling pathways (Table 3 ) and could be a new therapeutic avenue for neuroprotection.

Smad7 is an inactive record factor in pathogenesis of PD, which is constitutively upregulated in triggered microglia [54]. It leads DAergic neurons towards apoptosis by means of p53 and TGF- $\beta$ cascade. Interestingly, Pal et al. (2016) indicated that activators of either NF-KB (IL-1 $\beta$, TNF-a) or STAT-1 (IFN- $\gamma$ ) signaling pathways enhances the expression of Smad7 [54,55]. In the present study, we also found an 
upregulated expression of Smad7 in PD mice which is in agreement with the results of Uberham et al. (2006) whereas, its expression was downregulated after Tc treatment. Upregulation of Smad7 in triggered microglial cell has possessed threat to the neuroprotective TGF- $\beta 1$ signaling $[55,56]$. TGF- $\beta$ signaling favors cell survival by inactivating Bad (pro-apoptotic protein of the Bcl-2 family) thereby enhancing its phosphorylation through activation of the ERK/MAP kinase pathway. TGF- $\beta 1$ signaling also suppresses the secondary neuronal damage caused by neuroinflammation [57-59]. Thus, TGF- $\beta /$ Smad signaling pathway plays a crucial role in neuroprotection. Our results also suggests that Tc potentially suppresses the death of DAergic neurons via downregulation of Smad7 [54] .

Tfam (Mitochondrial Transcription Factor A) is a $25 \mathrm{kDa}$ DNA-binding protein contained in mtDNA. Tfam protects mtDNA from ROS, and mtDNA protects Tfam from Lon protease degradation [60,61]. Loss of Tfam expression was found to be linked with degeneration of the DAergic neurons [62], whereas its enhanced expression improves mitochondrial ailment phenotypes via accelerating mtDNA copy variety and delays neurodegeneration [63]. Consequently, Tfam is a good indicator of defects in mitochondrial integrity. In this study, we observed that ROT-intoxication upregulates Tfam expression whereas, its expression was downregulated by Tc pretreatment. Lu et al. (2018) also demonstrated a downregulated Tfam expression in ROT-intoxicated cultured SH-SY5Y [64,65]. Thus, it is suggested that by downregulating Tfam expression, Tc improved the mitochondrial function, which is a major pathogenic hallmark of PD.

Gpr37 is a substrate of the E3 ligase Parkin, and henceforth is also called Parkin-related endothelin-like receptor (Pael-R) [66]. Missense type of mutation in PARKIN causes aggregation of Gpr37 in brain of PD patients [67]. Besides, overexpression of Gpr37 prompts its amassing in totals causes ER stress, and neuronal death $[66,68]$. On other hand, it has been proposed that native Gpr37 shows neuroprotective property by binding prosaptide and prosaposin [69]. Interestingly, Lundius et al. (2013) reported that overexpression of Gpr37 was robustly protected against ROT, MPP+ or 6-OHDA-induced cytotoxicity in N2a cells [70]. Furthermore, it has been suggested that Gpr37 regulates oligodendrocyte separation and myelination by means of ERK signaling [71]. However, Tc-treatment to the PD mice suppresses the expression of Gpr37 in ROT-intoxicated mice model. Here, we present that Gpr37 plays a broader role in neuroprotective and glioprotective activity of Tc.

Tiam1 ( $T$ lymphoma invasion and metastasis 1 ) is a Rac-specific GEF (Dbl family member), potentially involved in neurodegenerative diseases (AD and PD). It is a Ras effector molecule, stimulated by the $\mathrm{Ca}^{2+}$ dependent activation of the NMDA receptor (NMDAR) [72]. Tiam1 controls the activation of Rho GTPase and plays an important role in PD by regulating oxidative stress and neuroinflammation [73]. Tiam1 controls neurite extension and DAergic neurons differentiation $[74,75]$. After exposing hippocampal neurons to amyloid- $\beta$ peptide, Tiam1 is activated and mobilized to the membrane, which may affect the pathology of $A D$ [76]. In the present study, expression of Tiam1 is downregulated by Tc extract treatment against ROT-intoxication. Interestingly, Smith et al. (2017) also reported that, an elevated expression of Tiam1 contributes to neuronal damage [77]. In contrast, Cajanek et al. (2013) showed, Tiam1 as a positive regulator of DAergic neuron differentiation [74]. Together, these studies indicate that ROT-induced 
neurotoxic effects are linked with an upregulated expression of Tiam1 and Tc reverts the ROT-induced neurotoxicity via downregulating Tiam1 expression.

Akt, a serine/threonine kinase [also known as protein kinase $B(P K B)$ ] is an important molecule necessary for neuronal survival as it plays a major role in phosphorylating its substrates, including GSK3, NF-KB, $B A D$, and forkhead proteins [78]. Downregulation of Akt signaling are seen in PD [79]. Previous studies suggested that PD-inducing neurotoxins including 6-OHDA and MPP+ decreases the expression of pAkt [80]. Durgadoss et al. (2012) demonstrated the Akt signaling impairment in the MPTP-induced mouse model, showing pAkt levels and loss of Akt kinase activity (Thr308 and Ser473). Similarly, we have also reported a downregulated expression of Akt1 in ROT-induced parkinsonian mice. Growing evidence also suggested the importance of mTOR pathway in autophagy and apoptosis which can lead to neuronal death, but later it was found that was the inhibition of the Akt phosphorylation, rather than mTOR activation that eventually led to neuronal loss [81]. Raghu et al. (2009) reported, activation of Akt by G14A (a polysaccharide from Tc) [82]. In an attempt to unravel the anti-apoptotic action of Tc against ROTintoxication, our study revealed an increased expression of Akt1, also supported by Salama et al. (2020) $[83,84]$.

The present study showed that Tc significantly reversed ROT-induced downregulation of Grin2A expression and exhibits neuroprotective effect against ROT-induced neurotoxicity. Moreover, downregulation of Grin2A (NR2A, a glutamate ionotropic NR type subunit 2A) expression resulted in $\mathrm{Ca}^{2+}$ mediated neurotoxicity. NRs (N-methyl-D-aspartate or NMDA receptors) play a crucial role in the pathogenesis of neurological disorders [85]. Reduced expression of the NRs was found in the patient's brain with neurodegenerative diseases $[86,87]$. NRs require proper complex formation between GRIN1 and GRIN2 (A-D) subunits to permit $\mathrm{Ca}^{2+}$ influx into the cell [88]. GRIN2A, regulates excitatory neurotransmission in the brain and thus plausibly influence the course of PD. Kong et al. (2015) confirmed that Grin2 is downregulated significantly in PD flies against a-synuclein neurotoxicity [89]. Interestingly, in present study we have documented a downregulated expression of Grin2A in ROT-induced parkinsonian mice, whereas, Tc upregulate the Grin2A expression against ROT-intoxication. Similarly, Simon et al. (2017) and Hamza et al. (2011) also reported Grin2A association with the risk of PD [86, 87]. Downregulation of Grin2A showed lack of binding to Grin1 resulting in reduced NMDAR complex formation. By considering all the aforementioned studies the potential of targeting Grin2A for the therapeutics of PD pathogenesis is confirmed. Tc plays an important role in attenuation of NMDARdependent $\mathrm{Ca}^{2+}$-mediated signaling via downregulating Grin2A.

Epigenetic dysregulation have emerged as important component in the PD pathogenesis [92]. Kdm3A is a JmjC (Jumonji) domain-containing lysine (K)-specific demethylase 3A. Kdm3A-mediated demethylation of PGC-1 a (Peroxisome proliferator-activated receptor gamma coactivator 1-alpha) causes inhibition of subsequent mitochondrial biogenesis and oxidative metabolism via reduction in PGC-1a and Nrf1/2 binding and Nrf1/2-dependent Tfam expression [93]. Dnmt 1 [DNA (cytosine-5)-methyltransferase 1] an enzyme catalyzing DNA methylation via methylating $\mathrm{CpGs}$ on hemimethylated DNA. Hypermethylation of 
PGC-1a promoter results in the reduction of PGC-1a protein expression. Downregulated PGC-1a exacerbates age-dependent neuroinflammation by enhancing the release of IL6 [94].

From the result of qRT-PCR, it is clearly evident that Smad7, Gpr37, Kdm3a, Dnmt1, and Tiam1 are increased in ROT-intoxicated mice, while it is significantly restored in Tc treated group. On the other hand, the mRNA level of Tfam, Akt1, and Grin2a were downregulated in ROT group while it was restored in Tc treated group. This demonstrates that Tc exhibits neuroprotection of DA neurons in ROT mice via regulating different signaling pathways at mRNA level.

Overall, epigenetic methylation of PGC-1a positively regulates initiation and progression of PD. Downregulation of PGC-1a via inhibition of Dnmts-mediated hypermethylation, or Kdm3A-mediated demethylation, play central role in PD pathogenesis by improving mitochondrial dysfunction, oxidative and inflammatory stress. In this study, results have shown the downregulation of Dnmts and Kdm3A gene after Tc treatment compared to ROT-induced parkinsonian mice. Hence, Tc may be a potential therapeutic agent for epigenetically modified targets in PD pathogenesis (Figure 8).

\section{Conclusions}

This study explored the neuroprotective effect of Tc in ROT-induced PD mouse model. Besides, we have also tried to explore the underlying mechanism of action in restoring the level of various protein molecules including Akt1, Smad7, Gpr37, Grin2A, Tiam1, Tfam, Dnmt1 and Kdm3a etc through proteomics and qRT-PCR. In conclusion, the overall findings of this study provides a new insight that Tc exerts therapeutic effect through the regulation of various signaling pathways by protecting the DAergic neurons and restoring mitochondrial function. However, further studies are needed to explore the bioactive components of Tc that play essential role in regulation of the disease.

\section{Declarations}

\section{- Acknowledgments}

SSS, HB, RS, WZ, ASR, and HD are sincerely thankful to ICMR, DBT, CSIR, and BHU, India, for their respective fellowship. The authors are also thankful to the head of the Department of Biochemistry, Institute of science, BHU, for providing the basic departmental facility.

\section{- Availability of data and materials}

All data generated or analyzed during this study are included in this article [and its supplementary information files].

\section{- Code availability}

Not Applicable 


\section{- Ethics approval and consent to participate}

This work has been approved by the Institutional Animal Ethical Committee (Reg no. BHU/DoZ/IAEC/2018-19/032), BHU, Varanasi, India.

\section{- Competing interests}

The authors declare that they have no competing interests.

\section{- Funding}

The author(s) received no financial support for this research.

\section{- Consent to participate}

Not Applicable

\section{- Consent for publication}

All authors provide their consent for publication

\section{- Authors' Contributions}

HB and SPS conceived, performed and designed experiments. HB, SPS, CK and HD wrote the manuscript. HB, SSS, WZ, ASR, RS processed mice tissue for proteomic analysis and perform behavior study. MR and HB perform bioinformatics analysis. All authors approved the final manuscript.

\section{References}

1. Ray Dorsey E, Elbaz A, Nichols E, Abd-Allah F, Abdelalim A, Adsuar JC, et al. Global, regional, and national burden of Parkinson's disease, 1990-2016: a systematic analysis for the Global Burden of Disease Study 2016. Lancet Neurol. 2018;

2. Feigin VL, Nichols E, Alam T, Bannick MS, Beghi E, Blake N, et al. Global, regional, and national burden of neurological disorders, 1990-2016: a systematic analysis for the Global Burden of Disease Study 2016. Lancet Neurol. 2019;

3. de Lau LM, Breteler MM. Epidemiology of Parkinson's disease. Lancet Neurol. 2006.

4. Tysnes OB, Storstein A. Epidemiology of Parkinson's disease. J. Neural Transm. 2017.

5. Zhang ZN, Zhang JS, Xiang J, Yu ZH, Zhang W, Cai M, et al. Subcutaneous rotenone rat model of Parkinson's disease: Dose exploration study. Brain Res. 2017;

6. Sulzer D, Surmeier DJ. Neuronal vulnerability, pathogenesis, and Parkinson's disease. Mov. Disord. 2013.

7. Cotzias GC, Papavasiliou PS, Gellene R. Modification of Parkinsonism - Chronic Treatment with LDopa. N Engl J Med. 1969; 
8. Tanner CM, Kame F, Ross GW, Hoppin JA, Goldman SM, Korell M, et al. Rotenone, paraquat, and Parkinson's disease. Environ Health Perspect. 2011;

9. El-Sayed EK, Ahmed AAE, Morsy EME, Nofal S. Neuroprotective effect of agmatine (decarboxylated Iarginine) against oxidative stress and neuroinflammation in rotenone model of Parkinson's disease. Hum Exp Toxicol. 2018;

10. Bordt EA, Clerc P, Roelofs BA, Saladino AJ, Tretter L, Adam-Vizi V, et al. The Putative Drp1 Inhibitor mdivi-1 Is a Reversible Mitochondrial Complex I Inhibitor that Modulates Reactive Oxygen Species. Dev Cell. 2017;

11. Salamon A, Zádori D, Szpisjak L, Klivényi P, Vécsei L. Neuroprotection in Parkinson's disease: facts and hopes. J. Neural Transm. 2020.

12. Rai SN, Birla H, Singh SS, Zahra W, Patil RR, Jadhav JP, et al. Mucuna pruriens protects against MPTP intoxicated neuroinflammation in Parkinson's disease through NF-KB/pAKT signaling pathways. Front Aging Neurosci. 2017;9.

13. Birla H, Keswani C, Rai SN, Singh SS, Zahra W, Dilnashin H, et al. Neuroprotective effects of Withania somnifera in BPA induced-cognitive dysfunction and oxidative stress in mice. Behav Brain Funct. 2019;15.

14. Jyoti A, Sharma D. Neuroprotective role of Bacopa monniera extract against aluminium-induced oxidative stress in the hippocampus of rat brain. Neurotoxicology. 2006;

15. Cummings J, Lee G, Mortsdorf T, Ritter A, Zhong K. Alzheimer's disease drug development pipeline: 2017. Alzheimer's Dement. Transl. Res. Clin. Interv. 2017.

16. Esposito E, Cuzzocrea S. New Therapeutic Strategy for Parkinsons and Alzheimers Disease. Curr Med Chem. 2010;

17. Sharma A, Bajaj P, Bhandari A, Kaur G. From ayurvedic folk medicine to preclinical neurotherapeutic role of a miraculous herb, Tinospora cordifolia. Neurochem Int. 2020;

18. Kosaraju J, Chinni S, Roy PD, Kannan E, Antony AS, Kumar MNS. Neuroprotective effect of Tinospora cordifolia ethanol extract on 6-hydroxy dopamine induced Parkinsonism. Indian J Pharmacol. 2014;

19. Birla H, Rai SN, Singh S Sen, Zahra W, Rawat A, Tiwari N, et al. Tinospora cordifolia Suppresses Neuroinflammation in Parkinsonian Mouse Model. NeuroMolecular Med. 2019;

20. Sharma A, Kalotra S, Bajaj P, Singh H, Kaur G. Butanol Extract of Tinospora cordifolia Ameliorates Cognitive Deficits Associated with Glutamate-Induced Excitotoxicity: A Mechanistic Study Using Hippocampal Neurons. NeuroMolecular Med. 2020;

21. Srivastava G, Singh K, Tiwari MN, Singh MP. Proteomics in Parkinsons disease: Current trends, translational snags and future possibilities. Expert Rev. Proteomics. 2010.

22. Conti A, Alessio M. Proteomics for Cerebrospinal Fluid Biomarker Identification in Parkinsons Disease: Methods and Critical Aspects. AIMS Med Sci. 2015;

23. Pienaar IS, Dexter DT, Burkhard PR. Mitochondrial proteomics as a selective tool for unraveling Parkinsons disease pathogenesis. Expert Rev. Proteomics. 2010. 
24. Kalra H, Adda CG, Liem M, Ang CS, Mechler A, Simpson RJ, et al. Comparative proteomics evaluation of plasma exosome isolation techniques and assessment of the stability of exosomes in normal human blood plasma. Proteomics. 2013;

25. Bantscheff M, Scholten A, Heck AJR. Revealing promiscuous drug-target interactions by chemical proteomics. Drug Discov. Today. 2009.

26. Sleno L, Emili A. Proteomic methods for drug target discovery. Curr. Opin. Chem. Biol. 2008.

27. Megger DA, Bracht T, Meyer HE, Sitek B. Label-free quantification in clinical proteomics. Biochim. Biophys. Acta - Proteins Proteomics. 2013.

28. Alara OR, Abdurahman NH, Ukaegbu Cl, Kabbashi NA. Extraction and characterization of bioactive compounds in Vernonia amygdalina leaf ethanolic extract comparing Soxhlet and microwaveassisted extraction techniques . J Taibah Univ Sci. 2019;

29. Prince PSM, Menon VP. Antioxidant action of Tinospora cordifolia root extract in alloxan diabetic rats. Phyther Res. 2001;

30. Ali H, Dixit S. Extraction optimization of Tinospora cordifolia and assessment of the anticancer activity of its alkaloid palmatine. Sci World J. 2013;

31. Zahra W, Rai SN, Birla H, Singh SS, Rathore AS, Dilnashin H, et al. Neuroprotection of rotenoneinduced parkinsonism by ursolic acid in pd mouse model. CNS Neurol Disord - Drug Targets. 2020;19.

32. Singh SS, Rai SN, Birla H, Zahra W, Rathore AS, Dilnashin H, et al. Neuroprotective Effect of Chlorogenic Acid on Mitochondrial Dysfunction-Mediated Apoptotic Death of da Neurons in a Parkinsonian Mouse Model. Oxid Med Cell Longev. 2020;2020.

33. Meredith GE, Kang UJ. Behavioral models of Parkinsons disease in rodents: A new look at an old problem. Mov. Disord. 2006.

34. Gupta SP, Patel S, Yadav S, Singh AK, Singh S, Singh MP. Involvement of nitric oxide in maneb-and paraquat-induced Parkinson's disease phenotype in mouse: Is there any link with lipid peroxidation? Neurochem Res. 2010;

35. Tillerson JL, Caudle WM, Reverón ME, Miller GW. Exercise induces behavioral recovery and attenuates neurochemical deficits in rodent models of Parkinson's disease. Neuroscience. 2003;

36. Bradford MM. A rapid and sensitive method for the quantitation of microgram quantities of protein utilizing the principle of protein-dye binding. Anal Biochem. 1976;

37. Clough T, Key M, Ott I, Ragg S, Schadow G, Vitek O. Protein quantification in label-free LC-MS experiments. J Proteome Res. 2009;

38. Shalit T, Elinger D, Savidor A, Gabashvili A, Levin Y. MS1-based label-free proteomics using a quadrupole orbitrap mass spectrometer. J Proteome Res. 2015;

39. Rajput M, Kumar M, Kumari M, Bhattacharjee A, Awasthi AA. Identification of key genes and construction of regulatory network for the progression of cervical cancer. Gene Reports. 2020;

40. Kangueane P. Protein-protein interactions. Protein-Protein Interact. 2011. 
41. Kanehisa M, Sato Y. KEGG Mapper for inferring cellular functions from protein sequences. Protein Sci. 2020;

42. Vlasblom J, Zuberi K, Rodriguez H, Arnold R, Gagarinova A, Deineko V, et al. Novel function discovery with GeneMANIA: A new integrated resource for gene function prediction in Escherichia coli. Bioinformatics. 2015;

43. Warde-Farley D, Donaldson SL, Comes O, Zuberi K, Badrawi R, Chao P, et al. The GeneMANIA prediction server: Biological network integration for gene prioritization and predicting gene function. Nucleic Acids Res. 2010;

44. Ellis JM, Fell MJ. Current approaches to the treatment of Parkinson's Disease. Bioorganic Med. Chem. Lett. 2017.

45. Garcia-Arencibia M, Garcia C, Fernandez-Ruiz J. Cannabinoids and Parkinsons Disease. CNS Neurol Disord - Drug Targets. 2012;

46. Johnson ME, Bobrovskaya L. An update on the rotenone models of Parkinson's disease: Their ability to reproduce the features of clinical disease and model gene-environment interactions. Neurotoxicology. 2015.

47. Schapira AHV, Cooper JM, Dexter D, Clark JB, Jenner P, Marsden CD. Mitochondrial Complex I Deficiency in Parkinson's Disease. J Neurochem. 1990;

48. Williams-Gray CH, Worth PF. Parkinson's disease. Med. (United Kingdom). 2020.

49. Schapira AHV, Chaudhuri KR, Jenner P. Non-motor features of Parkinson disease. Nat. Rev. Neurosci. 2017.

50. Birla H, Rai SN, Singh SS, Zahra W, Rawat A, Tiwari N, et al. Tinospora cordifolia Suppresses Neuroinflammation in Parkinsonian Mouse Model. NeuroMolecular Med. 2019;21.

51. Basnyat S, Kolasinski SL. Ayurvedic medicine for rheumatoid arthritis. Curr. Rheumatol. Rep. 2014.

52. B. K, D.E. G, J. H, K.A. N. Plant metal chaperones: A novel perspective in dementia therapy. Amyloid. 2009;

53. Sharma A, Kaur G. Tinospora cordifolia as a potential neuroregenerative candidate against glutamate induced excitotoxicity: An in vitro perspective 11 Medical and Health Sciences 1109 Neurosciences. BMC Complement Altern Med. 2018;

54. Pal R, Tiwari PC, Nath R, Pant KK. Role of neuroinflammation and latent transcription factors in pathogenesis of Parkinson's disease. Neurol. Res. 2016.

55. Koefer R, Streit WJ, Toyka K V., Kreutzberg GW, Hartung HP. Transforming growth factor- $\beta 1$ : A lesionassociated cytokine of the nervous system. Int J Dev Neurosci. 1995;

56. Ueberham U, Ueberham E, Gruschka H, Arendt T. Altered subcellular location of phosphorylated Smads in Alzheimer's disease. Eur J Neurosci. 2006;

57. Doyle KP, Cekanaviciute E, Mamer LE, Buckwalter MS. TGF $\beta$ signaling in the brain increases with aging and signals to astrocytes and innate immune cells in the weeks after stroke. $J$ Neuroinflammation. 2010; 
58. Dobolyi A, Vincze C, Pál G, Lovas G. The neuroprotective functions of transforming growth factor beta proteins. Int. J. Mol. Sci. 2012.

59. Krieglstein K, Henheik P, Farkas L, Jaszai J, Galter D, Krohn K, et al. Glial cell line-derived neurotrophic factor requires transforming growth factor- $\beta$ for exerting its full neurotrophic potential on peripheral and CNS neurons. J Neurosci. 1998;

60. Lu B, Lee J, Nie X, Li M, Morozov YI, Venkatesh S, et al. Phosphorylation of Human TFAM in Mitochondria Impairs DNA Binding and Promotes Degradation by the AAA+ Lon Protease. Mol Cell. 2013;

61. Larsson NG, Wang J, Wilhelmsson H, Oldfors A, Rustin P, Lewandoski M, et al. Mitochondrial transcription factor $A$ is necessary for mtDNA maintenance and embryogenesis in mice. Nat Genet. 1998;

62. Ekstrand MI, Terzioglu M, Galter D, Zhu S, Hofstetter C, Lindqvist E, et al. Progressive parkinsonism in mice with respiratory-chain-deficient dopamine neurons. Proc Natl Acad Sci U S A. 2007;

63. Nishiyama S, Shitara H, Nakada K, Ono T, Sato A, Suzuki H, et al. Over-expression of Tfam improves the mitochondrial disease phenotypes in a mouse model system. Biochem Biophys Res Commun. 2010;

64. Lu J, Chen S, Shen M, He Q, Zhang Y, Shi Y, et al. Mitochondrial regulation by pyrroloquinoline quinone prevents rotenone-induced neurotoxicity in Parkinson's disease models. Neurosci Lett. 2018;

65. Cheng Q, Chen J, Guo H, Lu J li, Zhou J, Guo X yu, et al. Pyrroloquinoline quinone promotes mitochondrial biogenesis in rotenone-induced Parkinson's disease model via AMPK activation. Acta Pharmacol Sin. 2020;

66. Imai Y, Soda M, Inoue H, Hattori N, Mizuno Y, Takahashi R. An unfolded putative transmembrane polypeptide, which can lead to endoplasmic reticulum stress, is a substrate of Parkin. Cell. 2001;

67. Obeso JA, Rodriguez-Oroz MC, Goetz CG, Marin C, Kordower JH, Rodriguez M, et al. Missing pieces in the Parkinson's disease puzzle. Nat. Med. 2010.

68. Marazziti D, Di Pietro C, Golini E, Mandillo S, Matteoni R, Tocchini-Valentini GP. Induction of macroautophagy by overexpression of the Parkinson's disease-associated GPR37 receptor. FASEB J. 2009;

69. Meyer RC, Giddens MM, Schaefer SA, Hall RA. GPR37 and GPR37L1 are receptors for the neuroprotective and glioprotective factors prosaptide and prosaposin. Proc Natl Acad Sci U S A. 2013;

70. Lundius EG, Stroth N, Vukojevië V, Terenius L, Svenningsson P. Functional GPR37 trafficking protects against toxicity induced by 6-OHDA, MPP+ or rotenone in a catecholaminergic cell line. J Neurochem. 2013;

71. Yang HJ, Vainshtein A, Maik-Rachline G, Peles E. G protein-coupled receptor 37 is a negative regulator of oligodendrocyte differentiation and myelination. Nat Commun. 2016;

72. Tolias KF, Bikoff JB, Burette A, Paradis S, Harrar D, Tavazoie S, et al. The Rac1-GEF Tiam1 couples the NMDA receptor to the activity-dependent development of dendritic arbors and spines. Neuron. 
2005;

73. Choi DH, Cristóvão AC, Guhathakurta S, Lee J, Joh TH, Beal MF, et al. NADPH oxidase 1-mediated oxidative stress leads to dopamine neuron death in Parkinson's disease. Antioxidants Redox Signal. 2012;

74. Cajanek L, Ganji RS, Henriques-Oliveira C, Theofilopoulos S, Konik P, Bryja V, et al. Tiam1 Regulates the Wnt/Dvl/Rac1 Signaling Pathway and the Differentiation of Midbrain Dopaminergic Neurons. Mol Cell Biol. 2013;

75. Shirazi Fard S, Kele J, Vilar M, Paratcha G, Ledda F. Tiam1 as a signaling mediator of Nerve Growth Factor-dependent neurite outgrowth. PLoS One. 2010;

76. Ma QL, Yang F, Calon F, Ubeda OJ, Hansen JE, Weisbart RH, et al. p21-activated kinase-aberrant activation and translocation in Alzheimer disease pathogenesis. J Biol Chem. 2008;

77. Smith KR, Rajgor D, Hanley JG. Differential regulation of the Rac1 GTPase-activating protein (GAP) BCR during oxygen/glucose deprivation in hippocampal and cortical neurons. J Biol Chem. 2017;

78. Rai SN, Dilnashin H, Birla H, Singh SS, Zahra W, Rathore AS, et al. The Role of PI3K/Akt and ERK in Neurodegenerative Disorders. Neurotox Res. 2019;35.

79. Emamian ES. AKT/GSK3 signaling pathway and schizophrenia. Front. Mol. Neurosci. 2012.

80. Wang C, Ko HS, Thomas B, Tsang F, Chew KCM, Tay SP, et al. Stress-induced alterations in parkin solubility promote parkin aggregation and compromise parkin's protective function. Hum Mol Genet. 2005;

81. Machado-Vieira R, Zanetti M V., Teixeira AL, Uno M, Valiengo LL, Soeiro-de-Souza MG, et al. Decreased AKT1/mTOR pathway mRNA expression in short-term bipolar disorder. Eur Neuropsychopharmacol. 2015;

82. Raghu R, Sharma D, Ramakrishnan R, Khanam S, Chintalwar GJ, Sainis KB. Molecular events in the activation of $B$ cells and macrophages by a non-microbial TLR4 agonist, G1-4A from Tinospora cordifolia. Immunol Lett. 2009;

83. Salama RM, Abdel-Latif GA, Abbas SS, El Magdoub HM, Schaalan MF. Neuroprotective effect of crocin against rotenone-induced Parkinson's disease in rats: Interplay between PI3K/Akt/mTOR signaling pathway and enhanced expression of miRNA-7 and miRNA-221. Neuropharmacology. 2020;

84. Wang C, Cai X, Hu W, Li Z, Kong F, Chen X, et al. Investigation of the neuroprotective effects of crocin via antioxidant activities in HT22 cells and in mice with Alzheimer's disease. Int J Mol Med. 2019;

85. Waxman EA, Lynch DR. N-methyl-D-aspartate receptor subtypes: Multiple roles in excitotoxicity and neurological disease. Neuroscientist. 2005.

86. Mishizen-Eberz AJ, Rissman RA, Carter TL, Ikonomovic MD, Wolfe BB, Armstrong DM. Biochemical and molecular studies of NMDA receptor subunits NR1/2A/2B in hippocampal subregions throughout progression of Alzheimer's disease pathology. Neurobiol Dis. 2004; 
87. Meoni P, Bunnemann BH, Kingsbury AE, Trist DG, Bowery NG. NMDA NR1 subunit mRNA and glutamate NMDA-sensitive binding are differentially affected in the striatum and pre-frontal cortex of Parkinson's disease patients. Neuropharmacology. 1999;

88. Prickett TD, Zerlanko BJ, Hill VK, Gartner JJ, Qutob N, Jiang J, et al. Somatic mutation of GRIN2A in malignant melanoma results in loss of tumor suppressor activity via aberrant NMDAR complex formation. J Invest Dermatol. 2014;

89. Kong Y, Liang X, Liu L, Zhang D, Wan C, Gan Z, et al. High throughput sequencing identifies MicroRNAs mediating a-synuclein toxicity by targeting neuroactive-ligand receptor interaction pathway in early stage of Drosophila Parkinson's disease model. PLoS One. 2015;

90. Hamza TH, Chen H, Hill-Burns EM, Rhodes SL, Montimurro J, Kay DM, et al. Genome-wide geneenvironment study identifies glutamate receptor gene grin2a as a parkinson's disease modifier gene via interaction with coffee. PLoS Genet. 2011;

91. Simon DK, Wu C, Tilley BC, Lohmann K, Klein C, Payami H, et al. Caffeine, creatine, GRIN2A and Parkinson's disease progression. J Neurol Sci. 2017;

92. Habibi E, Masoudi-Nejad A, Abdolmaleky HM, Haggarty SJ. Emerging roles of epigenetic mechanisms in Parkinson's disease. Funct. Integr. Genomics. 2011.

93. Qian X, Li X, Shi Z, Bai X, Xia Y, Zheng Y, et al. KDM3A Senses Oxygen Availability to Regulate PGC1a-Mediated Mitochondrial Biogenesis. Mol Cell. 2019;

94. Su X, Chu Y, Kordower JH, Li B, Cao H, Huang L, et al. PGC-1 a promoter methylation in Parkinson's disease. PLoS One. 2015;

\section{Tables}

Table 1a: list of down regulated protein in control vs. PD group. 


\begin{tabular}{|c|c|c|c|c|c|}
\hline Accession & Description & Gene & Score & Fold change & $\begin{array}{l}P \\
\text { values }\end{array}$ \\
\hline P40630 & Transcription factor A, mitochondrial & Tfam & 13.77 & 0.033708673 & 0.00 \\
\hline Q60I26 & ALS2 C-terminal-like protein & Als2cl & 34.84 & 0.103312182 & 0 \\
\hline Q7M6Z4 & Kinesin-like protein KIF27 & Kif27 & 77.06 & 0.114177608 & 0 \\
\hline Q9D8U2 & Transmembrane protein $41 \mathrm{~A}$ & Tmem41a & 48.37 & 0.155672628 & 0 \\
\hline Q8VC28 & $\begin{array}{l}\text { Aldo-keto reductase family } 1 \text { member } \\
\text { C13 }\end{array}$ & Akr1c13 & 8.74 & 0.170332992 & 0 \\
\hline Q3TD16 & Protein RUBCNL-like & Rubcnl & 6.94 & 0.173773943 & 0.02 \\
\hline Q9D4D7 & Cell cycle control protein $50 \mathrm{C}$ & Tmem30c & 111.69 & 0.177284407 & 0 \\
\hline P28481 & Collagen alpha-1(II) chain & Col2a1 & 26.09 & 0.184519513 & 0 \\
\hline Q8K4P0 & $\begin{array}{l}\text { pre-mRNA 3' end processing protein } \\
\text { WDR33 }\end{array}$ & Wdr33 & 33.73 & 0.218711891 & 0 \\
\hline Q9CXJ4 & $\begin{array}{l}\text { ATP-binding cassette sub-family B } \\
\text { member } 8 \text {, mitochondrial }\end{array}$ & Abcb8 & 31.47 & 0.22090998 & 0 \\
\hline Q9D824 & $\begin{array}{l}\text { Pre-mRNA 3'-end-processing factor } \\
\text { FIP1 }\end{array}$ & Fip1/1 & 61.28 & 0.236927745 & 0 \\
\hline D7PDD4 & $\begin{array}{l}\text { Megakaryocyte and platelet } \\
\text { inhibitory receptor } \mathrm{G} 6 \mathrm{~b}\end{array}$ & Mpig6b & 15.59 & 0.244143291 & 0.03 \\
\hline Q3V0B4 & $\begin{array}{l}\text { Cilia- and flagella-associated protein } \\
65\end{array}$ & Cfap65 & 46.43 & 0.24659697 & 0.02 \\
\hline Q3UZ18 & Little elongation complex subunit 2 & Ice2 & 62.94 & 0.249075308 & 0.08 \\
\hline Q3UFQ8 & $\begin{array}{l}\text { Capping protein, Arp } 2 / 3 \text { and myosin-I } \\
\text { linker protein } 3\end{array}$ & Carmil3 & 100.97 & 0.254106958 & 0.02 \\
\hline Q6VGS5 & Protein Daple & Ccdc88c & 82.65 & 0.267135288 & 0 \\
\hline P13439 & Uridine 5'-monophosphate synthase & Umps & 98.96 & 0.269820072 & 0 \\
\hline A0JP43 & $\begin{array}{l}\text { EF-hand calcium-binding domain- } \\
\text { containing protein } 5\end{array}$ & Efcab5 & 132.72 & 0.280831627 & 0 \\
\hline P58389 & $\begin{array}{l}\text { Serine/threonine-protein } \\
\text { phosphatase } 2 A \text { activator }\end{array}$ & Ptpa & 24.17 & 0.283654029 & 0.01 \\
\hline Q9JJA7 & Cyclin-L2 OS=Mus musculus & Ccnl2 & 64.77 & 0.286504797 & 0 \\
\hline Q65Z40 & Wings apart-like protein homolog & Wapl & 93.96 & 0.286504797 & 0.03 \\
\hline Q3USH5 & $\begin{array}{l}\text { Splicing factor, suppressor of white- } \\
\text { apricot homolog }\end{array}$ & Sfswap & 18.44 & 0.289384215 & 0 \\
\hline
\end{tabular}




\begin{tabular}{|c|c|c|c|c|c|}
\hline E9PY46 & $\begin{array}{l}\text { Intraflagellar transport protein } 140 \\
\text { homolog }\end{array}$ & Ift140 & 60.44 & 0.298197268 & 0 \\
\hline Q8BI84 & $\begin{array}{l}\text { Transport and Golgi organization } \\
\text { protein } 1 \text { homolog }\end{array}$ & Mia3 & 79.39 & 0.304221247 & 0 \\
\hline Q3UJV1 & $\begin{array}{l}\text { Coiled-coil domain-containing protein } \\
61\end{array}$ & Ccdc61 & 62.76 & 0.310366955 & 0.05 \\
\hline Q8VCE9 & $\begin{array}{l}\text { Pleckstrin homology domain- } \\
\text { containing family } \mathrm{H} \text { member } 3\end{array}$ & Plekhh3 & 41.21 & 0.319819026 & 0.01 \\
\hline Q402B2 & WD repeat-containing protein 93 & Wdr93 & 26.84 & 0.323033258 & 0.03 \\
\hline Q9DC22 & DDB1- and CUL4-associated factor 6 & Dcaf6 & 43.22 & 0.326279793 & 0 \\
\hline P0DM40 & Fer-1-like protein 5 & Fer115 & 64.41 & 0.329558956 & 0 \\
\hline Q80VW7 & $\begin{array}{l}\text { AT-hook-containing transcription } \\
\text { factor }\end{array}$ & Akna & 120.31 & 0.329558956 & 0.01 \\
\hline Q9CQ76 & Nephrocan OS=Mus musculus & Nepn & 62.73 & 0.339595511 & 0 \\
\hline Q8C7R4 & $\begin{array}{l}\text { Ubiquitin-like modifier-activating } \\
\text { enzyme } 6\end{array}$ & Uba6 & 70.72 & 0.34645583 & 0.02 \\
\hline Q9D9T8 & EF-hand domain-containing protein & Efhc1 & 41.5 & 0.357006971 & 0 \\
\hline P35761 & Dual specificity protein kinase TTK & Ttk & 55.54 & 0.360594947 & 0.04 \\
\hline Q69ZT1 & Fanconi-associated nuclease 1 & Fan1 & 58.77 & 0.367879441 & 0 \\
\hline 055123 & Stromelysin-2 & Mmp10 & 74.49 & 0.367879441 & 0 \\
\hline Q9D3S3 & Sorting nexin-29 & Snx29 & 90.72 & 0.375311092 & 0 \\
\hline Q8VC12 & Urocanate hydratase & Uroc1 & 17.94 & 0.379083027 & 0.03 \\
\hline P35436 & Glutamate receptor ionotropic, & Grin2a & 47.15 & 0.382892894 & 0.06 \\
\hline Q68SN8 & Fc receptor-like protein 5 & Fcrl5 & 36.2 & 0.386741028 & 0.01 \\
\hline Q61313 & Transcription factor AP-2-beta & Tfap2b & 265.96 & 0.394553708 & 0.06 \\
\hline 089032 & $\begin{array}{l}\mathrm{SH} 3 \text { and } \mathrm{PX} \text { domain-containing } \\
\text { protein } 2 \mathrm{~A}\end{array}$ & Sh3pxd2a & 63.67 & 0.394553708 & 0.02 \\
\hline 088444 & Adenylate cyclase type 1 & Adcy 1 & 29.94 & 0.402524213 & 0.02 \\
\hline Q6URW6 & Myosin-14 & Myh14 & 36.99 & 0.406569669 & 0.02 \\
\hline Q69ZX6 & $\begin{array}{l}\text { MORC family CW-type zinc finger } \\
\text { protein } 2 \mathrm{~A}\end{array}$ & Morc2a & 36.84 & 0.406569669 & 0.02 \\
\hline Q91YR5 & Methyltransferase-like protein 13 & Mettl13 & 70.63 & 0.406569669 & 0.06 \\
\hline P21784 & $\begin{array}{l}\mathrm{V}(\mathrm{D}) \mathrm{J} \text { recombination-activating } \\
\text { protein } 2\end{array}$ & Rag2 & 12.72 & 0.414782914 & 0.02 \\
\hline
\end{tabular}




\begin{tabular}{|c|c|c|c|c|c|}
\hline Q68FF0 & Uncharacterized protein KIAA1841 & Kiaa1841 & 184.57 & 0.414782914 & 0.02 \\
\hline 088573 & AF4/FMR2 family member 1 & Aff1 & 98.58 & 0.418951547 & 0.03 \\
\hline P97484 & $\begin{array}{l}\text { Leukocyte immunoglobulin-like } \\
\text { receptor subfamily B member } 3\end{array}$ & Lilrb3 & 79.83 & 0.427414922 & 0.09 \\
\hline Q1HKZ5 & $\begin{array}{l}\text { Mitogen-activated protein kinase } \\
\text { kinase kinase } 13\end{array}$ & Map3k13 & 96.18 & 0.427414922 & 0.04 \\
\hline Q80TH2 & Erbin & Erbin & 41.69 & 0.431710535 & 0.06 \\
\hline Q03391 & $\begin{array}{l}\text { Glutamate receptor ionotropic, NMDA } \\
2 D\end{array}$ & Grin2d & 79.79 & 0.436049294 & 0.03 \\
\hline A2RSJ4 & UHRF1-binding protein 1-like & Uhrf1bp1l & 73.99 & 0.440431658 & 0.09 \\
\hline Q6PGG2 & GEM-interacting protein & Gmip & 20.89 & 0.444858065 & 0.01 \\
\hline Q8CHB8 & Tubulin polyglutamylase TTLL5 & Ttll5 & 44.92 & 0.444858065 & 0.01 \\
\hline Q6ZPR6 & Inhibitor of Bruton tyrosine kinase & lbtk & 52.85 & 0.453844786 & 0.1 \\
\hline Q8BLR5 & $\begin{array}{l}\mathrm{PH} \text { and SEC7 domain-containing } \\
\text { protein } 4\end{array}$ & Psd4 & 69.96 & 0.453844786 & 0.07 \\
\hline Q8BRC6 & $\begin{array}{l}\text { Cilia- and flagella-associated protein } \\
91\end{array}$ & Maats1 & 58.96 & 0.463013077 & 0.06 \\
\hline Q9QUQ5 & $\begin{array}{l}\text { Short transient receptor potential } \\
\text { channel } 4\end{array}$ & Trpc4 & 4.32 & 0.463013077 & 0.21 \\
\hline Q9R1B9 & Slit homolog 2 protein & Slit2 & 93.96 & 0.467666431 & 0.19 \\
\hline Q61739 & Integrin alpha-6 & Itga6 & 56.04 & 0.467666431 & 0.01 \\
\hline Q9JIM3 & $\begin{array}{l}\text { DNA excision repair protein ERCC-6- } \\
\text { like } 2\end{array}$ & Ercc612 & 126.09 & 0.477113911 & 0 \\
\hline P97868 & E3 ubiquitin-protein ligase RBBP6 & Rbbp6 & 123.07 & 0.477113911 & 0 \\
\hline Q64521 & $\begin{array}{l}\text { Glycerol-3-phosphate } \\
\text { dehydrogenase, mitochondrial }\end{array}$ & Gpd2 & 34.65 & 0.481908981 & 0.01 \\
\hline 035595 & Protein patched homolog 2 & Ptch2 & 47.13 & 0.481908981 & 0.15 \\
\hline COLLJO & Importin subunit alpha-8 & Kpna7 & 156.9 & 0.486752242 & 0 \\
\hline Q9Z1N9 & Protein unc-13 homolog B & Unc13b & 78.66 & 0.491644208 & 0.02 \\
\hline Q8VDR9 & Dedicator of cytokinesis protein 6 & Dock6 & 57.98 & 0.491644208 & 0.03 \\
\hline Q91WJ8 & $\begin{array}{l}\text { Far upstream element-binding } \\
\text { protein } 1\end{array}$ & Fubp1 & 148.29 & 0.491644208 & 0.24 \\
\hline Q6V3W6 & Dynein regulatory complex subunit 7 & Drc7 & 45.09 & 0.49658531 & 0.03 \\
\hline Q80TI1 & $\begin{array}{l}\text { Pleckstrin homology domain- } \\
\text { containing family } \mathrm{H} \text { member } 1\end{array}$ & Plekhh1 & 22.44 & 0.49658531 & 0.04 \\
\hline
\end{tabular}




\begin{tabular}{|llllll|}
\hline D3Z3C6 & AN1-type zinc finger protein 4 & Zfand4 & 34.17 & 0.49658531 & 0.04 \\
\hline Q62252 & Sperm surface protein Sp17 & Spa17 & 10.47 & 0.49658531 & 0.09 \\
\hline P31750 & $\begin{array}{l}\text { RAC-alpha serine/threonine-protein } \\
\text { kinase }\end{array}$ & Akt1 & 53.76 & 0.50157607 & 0.03 \\
\hline Q8BL66 & Early endosome antigen 1 & Eea1 & 34.06 & 0.50157607 & 0.01 \\
\hline Q76MZ3 & $\begin{array}{l}\text { Serine/threonine-protein } \\
\text { phosphatase 2A 65 kDa regulatory } \\
\text { subunit A alpha isoform }\end{array}$ & Ppp2r1a & 106.4 & 0.516851321 & 0.15 \\
\hline P53762 & $\begin{array}{l}\text { Aryl hydrocarbon receptor nuclear } \\
\text { translocator }\end{array}$ & Arnt & 16.58 & 0.522045789 & 0.16 \\
\hline Q05D44 & $\begin{array}{l}\text { Eukaryotic translation initiation } \\
\text { factor 5B }\end{array}$ & Eif5b & 20.03 & 0.527292432 & 0 \\
\hline
\end{tabular}

Table 1b: list of up-regulated protein in control vs. PD group. 


\begin{tabular}{|c|c|c|c|c|c|}
\hline Accession & Description & Gene & Score & Fold change & $\begin{array}{l}P \\
\text { values }\end{array}$ \\
\hline Q3US17 & Zinc finger protein 48 & Znf48 & 53.45 & 2.033991215 & 0.94 \\
\hline Q9DBV3 & $\begin{array}{l}\text { Probable ATP-dependent RNA } \\
\text { helicase DHX34 }\end{array}$ & Dhx34 & 26.81 & 2.054433269 & 0.84 \\
\hline Q69ZH9 & Rho GTPase-activating protein 23 & Arhgap23 & 85.29 & 2.075080647 & 0.99 \\
\hline Q6PCM1 & Lysine-specific demethylase $3 \mathrm{~A}$ & $\mathrm{Kdm} 3 \mathrm{a}$ & 73.5 & 2.075080647 & 0.1 \\
\hline Q61410 & cGMP-dependent protein kinase 2 & Prkg2 & 48.47 & 2.095935534 & 0.99 \\
\hline Q78PY7 & $\begin{array}{l}\text { Staphylococcal nuclease domain- } \\
\text { containing protein } 1\end{array}$ & Snd1 & 49.95 & 2.095935534 & 0.93 \\
\hline Q61712 & $\begin{array}{l}\text { DnaJ homolog subfamily } \mathrm{C} \text { member } \\
1\end{array}$ & Dnajc1 & 179.33 & 2.095935534 & 0.98 \\
\hline 008644 & Ephrin type-B receptor 6 & Ephb6 & 57.2 & 2.117000017 & 0.82 \\
\hline Q2TV84 & $\begin{array}{l}\text { Transient receptor potential cation } \\
\text { channel subfamily } \mathrm{M} \text { member } 1\end{array}$ & Trpm1 & 70.19 & 2.117000017 & 0.99 \\
\hline Q9DBT3 & $\begin{array}{l}\text { Coiled-coil domain-containing protein } \\
97\end{array}$ & Ccdc97 & 163.38 & 2.117000017 & 0.96 \\
\hline Q3UYK3 & $\begin{array}{l}\text { TBC1 domain family member } 9 \\
\text { OS }=\text { Mus musculus } O X=10090 \mathrm{GN}= \\
\mathrm{PE}=2 \mathrm{SV}=2\end{array}$ & Tbc1d9 & 34.44 & 2.1382762 & 0.82 \\
\hline Q8BXZ1 & Protein disulfide-isomerase TMX3 & $\operatorname{Tm} \times 3$ & 78.36 & 2.1382762 & 0.85 \\
\hline Q60520 & $\begin{array}{l}\text { Paired amphipathic helix protein } \\
\text { Sin3a }\end{array}$ & $\operatorname{Sin} 3 a$ & 56.89 & 2.159766213 & 0.91 \\
\hline A2AVR2 & $\begin{array}{l}\text { Maestro heat-like repeat-containing } \\
\text { protein family member } 7\end{array}$ & Mroh7 & 44.46 & 2.203396474 & 1 \\
\hline Q3U821 & WD repeat-containing protein 75 & Wdr75 & 56.32 & 2.203396474 & 0.75 \\
\hline 035253 & $\begin{array}{l}\text { Mothers against decapentaplegic } \\
\text { homolog } 7\end{array}$ & Smad7 & 124.06 & 2.247907992 & 0.76 \\
\hline Q8CIQ7 & Dedicator of cytokinesis protein 3 & Dock3 & 61.43 & 2.247907992 & 1 \\
\hline Q5IR70 & $\begin{array}{l}\text { Cancer-associated gene } 1 \text { protein } \\
\text { homolog }\end{array}$ & Cage1 & 72.97 & 2.247907992 & 1 \\
\hline Q8VDG6 & $\begin{array}{l}\text { Mitogen-activated protein kinase } \\
\text { kinase kinase } 21\end{array}$ & Map3k21 & 63.8 & 2.247907992 & 0.97 \\
\hline Q6P549 & $\begin{array}{l}\text { Phosphatidylinositol 3,4,5- } \\
\text { trisphosphate 5-phosphatase } 2\end{array}$ & Inppl1 & 58.2 & 2.247907992 & 0.98 \\
\hline P55937 & Golgin subfamily A member 3 & Golga3 & 96.77 & 2.293318702 & 0.96 \\
\hline
\end{tabular}




\begin{tabular}{|c|c|c|c|c|c|}
\hline Q8R3N1 & Nucleolar protein 14 & Nop14 & 79.3 & 2.293318702 & 0.99 \\
\hline 088207 & Collagen alpha-1(V) chain & Col5a1 & 59.36 & 2.316366916 & 0.93 \\
\hline Q9Z103 & $\begin{array}{l}\text { Activity-dependent neuroprotector } \\
\text { homeobox protein }\end{array}$ & Adnp & 89.03 & 2.316366916 & 1 \\
\hline Q91V83 & TELO2-interacting protein 1 homolog & Tti1 & 15.61 & 2.339646908 & 0.98 \\
\hline Q80WJ6 & $\begin{array}{l}\text { Multidrug resistance-associated } \\
\text { protein } 9\end{array}$ & Abcc12 & 13.84 & 2.339646908 & 0.99 \\
\hline Q8CGM1 & $\begin{array}{l}\text { Adhesion G protein-coupled receptor } \\
\text { B2 }\end{array}$ & Adgrb2 & 27.72 & 2.339646908 & 1 \\
\hline Q9WTP5 & Cadherin-22 & Cdh22 & 14.61 & 2.363160728 & 0.97 \\
\hline Q09M02 & $\begin{array}{l}\text { Cytosolic carboxypeptidase-like } \\
\text { protein } 5\end{array}$ & Agbl5 & 67.6 & 2.363160728 & 1 \\
\hline Q8C262 & Interferon-inducible GTPase 5 & $\operatorname{Irgc}$ & 52.61 & 2.386910865 & 0.82 \\
\hline Q8R5C8 & $\begin{array}{l}\text { Zinc finger MYND domain-containing } \\
\text { protein } 11\end{array}$ & Zmynd11 & 38.62 & 2.410899695 & 0.99 \\
\hline Q9Z280 & Phospholipase D1 & Pld1 & 41.71 & 2.459603053 & 0.98 \\
\hline 035134 & $\begin{array}{l}\text { DNA-directed RNA polymerase I } \\
\text { subunit RPA1 }\end{array}$ & Polr1a & 66.4 & 2.559981412 & 0.97 \\
\hline P70298 & Homeobox protein cut-like 2 & Cux2 & 52.91 & 2.559981412 & 0.81 \\
\hline Q02788 & Collagen alpha-2(VI) chain & Col6a2 & 122.36 & 2.585709628 & 1 \\
\hline B9EJ80 & PDZ domain-containing protein 8 & Pdzd8 & 125.57 & 2.637944535 & 0.92 \\
\hline Q9Z315 & $\begin{array}{l}\text { U4/U6.U5 tri-snRNP-associated } \\
\text { protein } 1\end{array}$ & Sart1 & 89.04 & 2.637944535 & 0.92 \\
\hline Q3UHX0 & Nucleolar protein 8 & Nol8 & 36.16 & 2.745600989 & 0.95 \\
\hline Q922B9 & Sperm-specific antigen 2 homolog & Ssfa2 & 38.63 & 2.773194711 & 1 \\
\hline 088393 & $\begin{array}{l}\text { Transforming growth factor beta } \\
\text { receptor type } 3\end{array}$ & Tgfbr3 & 40.02 & 2.857650982 & 0.96 \\
\hline Q60592 & $\begin{array}{l}\text { Microtubule-associated } \\
\text { serine/threonine-protein kinase } 2\end{array}$ & Mast2 & 49.97 & 2.944679677 & 0.99 \\
\hline Q69Z38 & $\begin{array}{l}\text { Pseudopodium-enriched atypical } \\
\text { kinase } 1\end{array}$ & Peak1 & 55.29 & 2.944679677 & 1 \\
\hline Q0VF58 & Collagen alpha- $1(X \mid X)$ chain & Col19a1 & 44.36 & 3.034358438 & 0.95 \\
\hline Q8K368 & $\begin{array}{l}\text { Fanconi anemia group I protein } \\
\text { homolog }\end{array}$ & Fanci & 29.85 & 3.064854218 & 0.97 \\
\hline Q6P5D4 & Centrosomal protein of $135 \mathrm{kDa}$ & Cep135 & 58.95 & 3.064854218 & 1 \\
\hline
\end{tabular}




\begin{tabular}{|c|c|c|c|c|c|}
\hline Q9R0L6 & Pericentriolar material 1 protein & Pcm1 & 72.96 & 3.064854218 & 0.78 \\
\hline Q8BZ81 & $\begin{array}{l}\text { Leucine-rich repeat transmembrane } \\
\text { neuronal protein } 3\end{array}$ & Lrrtm3 & 4.51 & 3.095656485 & 0.96 \\
\hline Q4QY64 & $\begin{array}{l}\text { ATPase family AAA domain- } \\
\text { containing protein } 5\end{array}$ & Atad5 & 45.34 & 3.158192834 & 0.99 \\
\hline Q60767 & Lymphocyte antigen 75 & Ly75 & 76.17 & 3.158192834 & 0.97 \\
\hline Q6PFQ7 & Ras GTPase-activating protein 4 & Rasa4 & 50.73 & 3.2219925 & 1 \\
\hline Q8CJ19 & [F-actin]-monooxygenase MICAL3 & Mical3 & 92.55 & 3.287081395 & 1 \\
\hline Q8R2Q4 & $\begin{array}{l}\text { Ribosome-releasing factor } 2 \\
\text { mitochondrial }\end{array}$ & Gfm2 & 145.38 & 3.287081395 & 0.95 \\
\hline Q6PDH0 & $\begin{array}{l}\text { Pleckstrin homology-like domain } \\
\text { family B member } 1\end{array}$ & Phldb1 & 48.26 & 3.35348478 & 1 \\
\hline Q9D2Y5 & Sorting nexin-20 & Snx20 & 125.27 & 3.455613498 & 0.96 \\
\hline Q8K1M6 & Dynamin-1-like protein & Dnm1 & 93.75 & 3.525421454 & 0.98 \\
\hline Q8K4G5 & Actin-binding LIM protein 1 & Ablim1 & 138.74 & 3.525421454 & 1 \\
\hline Q3TZ89 & Protein transport protein Sec31B & $\operatorname{Sec} 31 b$ & 26.71 & 3.669296493 & 1 \\
\hline Q9R020 & $\begin{array}{l}\text { Zinc finger Ran-binding domain- } \\
\text { containing protein }\end{array}$ & Zranb2 & 71.65 & 3.743421574 & 1 \\
\hline Q8R3K3 & $\begin{array}{l}\text { Pentatricopeptide repeat-containing } \\
\text { protein } 2 \text {, mitochondrial }\end{array}$ & Ptcd2 & 133.7 & 3.78104355 & 1 \\
\hline Q8JZX4 & Splicing factor 45 & Rbm17 & 191.31 & 3.857425623 & 0.96 \\
\hline Q80YR2 & Protein FAM160B2 & Fam16 & 82.59 & 3.896193358 & 1 \\
\hline P18608 & $\begin{array}{l}\text { Non-histone chromosomal protein } \\
\text { HMG-14 }\end{array}$ & Hmgn1 & 63.86 & 4.05519987 & 1 \\
\hline Q80Z10 & Astrotactin-2 & Astn2 & 113.17 & 4.095955267 & 1 \\
\hline Q69ZZ6 & $\begin{array}{l}\text { Transmembrane and coiled-coil } \\
\text { domains protein } 1\end{array}$ & Tmcc1 & 105.42 & 4.095955267 & 0.99 \\
\hline Q9D8M4 & $60 S$ ribosomal protein L7-like 1 & Rpl7I1 & 98.5 & 4.137120263 & 1 \\
\hline Q64455 & $\begin{array}{l}\text { Receptor-type tyrosine-protein } \\
\text { phosphatase eta }\end{array}$ & Ptprj & 82.44 & 4.178698973 & 1 \\
\hline Q9CZH8 & $\begin{array}{l}\text { Coiled-coil domain-containing protein } \\
77\end{array}$ & Ccdc77 & 68.39 & 4.220696059 & 1 \\
\hline P19426 & $\begin{array}{l}\text { Negative elongation factor } E \text { OS }=\text { Mus } \\
\text { musculus } O X=10090 \mathrm{GN}=\mathrm{PE}=1 \mathrm{SV}=2\end{array}$ & Nelfe & 233.74 & 4.220696059 & 1 \\
\hline Q8BYR2 & $\begin{array}{l}\text { Serine/threonine-protein kinase } \\
\text { LATS1 }\end{array}$ & Lats1 & 82.67 & 4.392945765 & 1 \\
\hline
\end{tabular}




\begin{tabular}{|c|c|c|c|c|c|}
\hline 035227 & $\begin{array}{l}\text { Disintegrin and metalloproteinase } \\
\text { domain-containing protein } 7\end{array}$ & Adam7 & 84.53 & 4.572225108 & 0.99 \\
\hline Q8K1K4 & Centromere protein I & Cenpi & 32.05 & 4.61817669 & 0.1 \\
\hline Q6ZQK0 & Condensin-2 complex subunit D3 & Ncapd3 & 19.64 & 4.61817669 & 0.89 \\
\hline Q8R516 & E3 ubiquitin-protein ligase MIB2 & Mib2 & 97.88 & 4.61817669 & 0.97 \\
\hline Q62190 & $\begin{array}{l}\text { Macrophage-stimulating protein } \\
\text { receptor }\end{array}$ & Mst1r & 36.56 & 4.711469958 & 1 \\
\hline Q5PRF0 & HEAT repeat-containing protein $5 \mathrm{~A}$ & Heatr5a & 173.88 & 4.953032542 & 1 \\
\hline Q04592 & $\begin{array}{l}\text { Proprotein convertase subtilisin/kexin } \\
\text { type } 5\end{array}$ & Pcsk5 & 118.56 & 5.053090341 & 1 \\
\hline Q3UWM4 & Lysine-specific demethylase 7A & Kdm7a & 117.3 & 5.419481015 & 1 \\
\hline A2ARA8 & Integrin alpha-8 & $\operatorname{ltga8}$ & 111.53 & 5.528961689 & 0.99 \\
\hline Q80TK0 & Uncharacterized protein KIAA1107 & Kiaa1107 & 56.56 & 5.697343477 & 0.99 \\
\hline Q8BTT6 & $\begin{array}{l}\text { Digestive organ expansion factor } \\
\text { homolog }\end{array}$ & Diexf & 22.27 & 6.423736863 & 1 \\
\hline Q80TQ2 & $\begin{array}{l}\text { Ubiquitin carboxyl-terminal hydrolase } \\
\text { CYLD }\end{array}$ & Cyld & 128.62 & 7.242743123 & 0.45 \\
\hline 089114 & $\begin{array}{l}\text { DnaJ homolog subfamily B member } \\
5\end{array}$ & Dnajb5 & 104.76 & 7.242743123 & 1 \\
\hline Q8K1N2 & $\begin{array}{l}\text { Pleckstrin homology-like domain } \\
\text { family B member } 2\end{array}$ & Phldb2 & 148.05 & 7.924822589 & 0.95 \\
\hline Q9DBM2 & Peroxisomal bifunctional enzyme & Ehhadh & 22.72 & 8.935213626 & 1 \\
\hline Q8CFE4 & SCY1-like protein 2 & Scyl2 & 20.66 & 11.02317743 & 1 \\
\hline Q8BWZ3 & $\begin{array}{l}\mathrm{N} \text {-alpha-acetyltransferase } 25, \text { NatB } \\
\text { auxiliary subunit }\end{array}$ & Naa25 & 34.99 & 11.24586017 & 1 \\
\hline Q8VCC9 & Spondin-1 & Spon1 & 14.42 & 12.06127624 & 0.99 \\
\hline Q8BH53 & $\begin{array}{l}\text { Cilia- and flagella-associated protein } \\
69\end{array}$ & Cfap69 & 40.4 & 13.06582357 & 1 \\
\hline Q99MV7 & RING finger protein 17 & Rnf17 & 80.2 & 15.48698524 & 1 \\
\hline Q9D6A1 & Unconventional myosin-lh & Myo1h & 25.15 & 16.94545953 & 1 \\
\hline Q62234 & Myomesin-1 & Myom1 & 79.57 & 18.1741471 & 1 \\
\hline Q9EPR5 & $\begin{array}{l}\text { VPS10 domain-containing receptor } \\
\text { SorCS2 }\end{array}$ & Sorcs2 & 136.48 & 18.91584739 & 1 \\
\hline Q569L8 & Centromere protein $\mathrm{J}$ & Cenpj & 29.79 & 20.697232 & 1 \\
\hline
\end{tabular}




\begin{tabular}{|c|c|c|c|c|c|}
\hline P97369 & Neutrophil cytosol factor 4 & Ncf4 & 43.81 & 23.33606681 & 1 \\
\hline P23116 & $\begin{array}{l}\text { Eukaryotic translation initiation factor } \\
3 \text { subunit A }\end{array}$ & Eif3a & 79.2 & 24.77908717 & 1 \\
\hline Q9JLG8 & Calpain-15 & Capn15 & 38.93 & 28.50273093 & 1 \\
\hline Q9D4K7 & $\begin{array}{l}\text { Coiled-coil domain-containing protein } \\
105\end{array}$ & Ccdc105 & 24.52 & 29.37077447 & 0.99 \\
\hline Q8BMA5 & Protein NPAT & Npat & 66.01 & 38.47466972 & 0.99 \\
\hline Q9QY42 & Prosaposin receptor GPR37 & Gpr37 & 191.96 & 57.39746799 & 0.23 \\
\hline Q60610 & $\begin{array}{l}\text { T-lymphoma invasion and } \\
\text { metastasis-inducing protein } 1\end{array}$ & Tiam1 & 170.78 & 126.469371 & 0.2 \\
\hline Q99PP7 & E3 ubiquitin-protein ligase TRIM33 & Trim33 & 92.95 & 139.7702576 & 1 \\
\hline Q8K352 & $\begin{array}{l}\text { SAM and SH3 domain-containing } \\
\text { protein } 3\end{array}$ & Sash3 & 41.94 & 639.0610809 & 1 \\
\hline
\end{tabular}

Table 2a: list of down-regulated protein in PD vs. Treatment group. 


\begin{tabular}{|c|c|c|c|c|c|}
\hline Accession & Description & Gene & Score & $\begin{array}{l}\text { Fold } \\
\text { change }\end{array}$ & $\begin{array}{l}P \\
\text { values }\end{array}$ \\
\hline Q8K440 & $\begin{array}{l}\text { ATP-binding cassette sub-family A } \\
\text { member 8-B }\end{array}$ & Abca8b & 4.22 & 0.069948 & 0 \\
\hline P97369 & Neutrophil cytosol factor 4 & Ncf4 & 49.82 & 0.132655 & 0 \\
\hline Q6PFX7 & $\begin{array}{l}\text { Neuronal tyrosine-phosphorylated } \\
\text { phosphoinositide-3-kinase adapter } 1\end{array}$ & Nyap1 & 4.91 & 0.163654 & 0 \\
\hline P13864 & DNA (cytosine-5)-methyltransferase 1 & Dnmt1 & 44.99 & 0.214381 & 0 \\
\hline Q8R1Q0 & Syntaxin-19 & Stx19 & 26.01 & 0.261846 & 0.01 \\
\hline Q8R5C8 & $\begin{array}{l}\text { Zinc finger MYND domain-containing } \\
\text { protein } 11\end{array}$ & Zmynd11 & 20.04 & 0.275271 & 0 \\
\hline Q8K1K4 & Centromere protein I & Cenpi & 22.85 & 0.440432 & 0.03 \\
\hline Q8BZQ7 & Anaphase-promoting complex subunit 2 & Anapc2 & 20.56 & 0.467666 & 0 \\
\hline Q8BZ05 & $\begin{array}{l}\text { Arf-GAP with Rho-GAP domain, ANK repeat } \\
\text { and PH domain-containing protein } 2\end{array}$ & Arap2 & 25.48 & 0.491644 & 0 \\
\hline P31750 & RAC-alpha serine/threonine-protein kinase & Akt1 & 63.32 & 0.511709 & 0.14 \\
\hline Q6PCM1 & Lysine-specific demethylase $3 \mathrm{~A}$ & $\mathrm{Kdm} 3 \mathrm{a}$ & 14.41 & 0.52722 & 0.14 \\
\hline 035253 & $\begin{array}{l}\text { Mothers against decapentaplegic homolog } \\
7\end{array}$ & Smad7 & 39.84 & 0.55988 & 0 \\
\hline Q6P549 & $\begin{array}{l}\text { Phosphatidylinositol 3,4,5-trisphosphate 5- } \\
\text { phosphatase } 2\end{array}$ & Inppl1 & 15.62 & 0.56555 & 0.03 \\
\hline Q9Z280 & Phospholipase D1 & Pld1 & 45.45 & 0.606531 & 0.2 \\
\hline Q8R2Q4 & Ribosome-releasing factor 2, mitochondrial & Gfm2 & 24.03 & 0.612626 & 0.01 \\
\hline Q60610 & $\begin{array}{l}\text { T-lymphoma invasion and metastasis- } \\
\text { inducing protein } 1\end{array}$ & Tiam1 & 31.11 & 0.650509 & 0.07 \\
\hline Q80TQ2 & $\begin{array}{l}\text { Ubiquitin carboxyl-terminal hydrolase } \\
\text { CYLD }\end{array}$ & Cyld & 16.8 & 0.657047 & 0.03 \\
\hline Q9QY42 & Prosaposin receptor GPR37 & Gpr37 & 10.31 & 0.66365 & 0.07 \\
\hline Q64455 & $\begin{array}{l}\text { Receptor-type tyrosine-protein } \\
\text { phosphatase eta }\end{array}$ & Ptprj & 7.7 & 0.66365 & 0.01 \\
\hline
\end{tabular}

Table 2b: list of up-regulated protein in PD vs. treatment group. 


\begin{tabular}{|llllll|}
\hline Accession & Description & Gene & Score & $\begin{array}{l}\text { Fold } \\
\text { change }\end{array}$ & $\begin{array}{c}\text { P } \\
\text { values }\end{array}$ \\
\hline P31750 & RAC-alpha serine/threonine-protein kinase & Akt1 & 63.32 & 1.877611 & 0.81 \\
\hline P40630 & Transcription factor A, mitochondrial & Tfam & 93.78 & 1.879013 & 1 \\
\hline Q3UH60 & Disco-interacting protein 2 homolog B & Dip2b & 33.8 & 2.013753 & 0.92 \\
\hline Q9DAZ9 & Abscission/NoCut checkpoint regulator & Zfyve19 & 173.52 & 2.159766 & 0.96 \\
\hline Q80T11 & Usher syndrome type-1G protein homolog & Ush1g & 17.67 & 2.4109 & 0.98 \\
\hline P53762 & $\begin{array}{l}\text { Aryl hydrocarbon receptor nuclear } \\
\text { translocator }\end{array}$ & Arnt & 16.58 & 2.43513 & 0.91 \\
\hline Q76MZ3 & $\begin{array}{l}\text { Serine/threonine-protein phosphatase 2A } \\
\text { 65 kDa regulatory subunit A alpha isoform }\end{array}$ & Ppp2r1a & 10.16 & 2.534509 & 0.93 \\
\hline Q8BL66 & Early endosome antigen 1 & Eea1 & 34.06 & 3.095656 & 0.86 \\
\hline Q6PFQ7 & Ras GTPase-activating protein 4 & Rasa4 & 30.1 & 3.221993 & 1 \\
\hline Q6P9K8 & Caskin-1 & Caskin1 & 11.12 & 3.287081 & 1 \\
\hline P70208 & Plexin-A3 & Plxna3 & 13.23 & 3.59664 & 1 \\
\hline P70670 & $\begin{array}{l}\text { Nascent polypeptide-associated complex } \\
\text { subunit alpha, muscle-specific form }\end{array}$ & Naca & 31.4 & 7.690609 & 1 \\
\hline Q5SXJ3 & Fanconi anemia group J protein homolog & Brip1 & 22.12 & 9.874937 & 0.07 \\
\hline Q05D44 & Eukaryotic translation initiation factor 5B & Eif5b & 20.03 & 11.24586 & 0.08 \\
\hline Q9QUQ5 & $\begin{array}{l}\text { Short transient receptor potential channel } \\
\text { 4 }\end{array}$ & Trpc4 & 7.04 & 1.822119 & 1 \\
\hline P35436 & Glutamate receptor ionotropic, NMDA 2A & Grin2a & 9 & 1.584074 & 1 \\
\hline
\end{tabular}

\section{Table 3: The Enriched Wikipathway.}

Significant Pathway Enrichment Analysis through Web gestalt Wikipathway 


\begin{tabular}{|llcllll|}
\hline $\begin{array}{l}\text { Gene } \\
\text { Set }\end{array}$ & Description & Size & Expect & Ratio & P Value & FDR \\
\hline WP3673 & Hfe effect on hepcidin production & 7 & 0.0076 & 131.57 & 0.007581 & 1 \\
\hline WP1263 & Mitochondrial Gene Expression & 19 & 0.02063 & 48.474 & 0.020469 & 1 \\
\hline WP1246 & $\begin{array}{l}\text { Hypothetical Network for Drug } \\
\text { Addiction }\end{array}$ & 31 & 0.033659 & 29.71 & 0.033223 & 1 \\
\hline WP3638 & Parkinsons Disease Pathway & 39 & 0.042345 & 23.615 & 0.041652 & 1 \\
\hline WP113 & TGF Beta Signaling Pathway & 52 & 0.05646 & 17.712 & 0.055223 & 1 \\
\hline WP3632 & Lung fibrosis & 61 & 0.066232 & 15.098 & 0.064528 & 1 \\
\hline WP2075 & Alzheimers Disease & 75 & 0.081433 & 12.28 & 0.078857 & 1 \\
\hline WP339 & ESC Pluripotency Pathways & 118 & 0.12812 & 7.8051 & 0.12177 & 1 \\
\hline WP1397 & Odorant GPCRs & 189 & 0.20521 & 4.873 & 0.18912 & 1 \\
\hline WP2292 & Chemokine signaling pathway & 190 & 0.2063 & 4.8474 & 0.19004 & 1 \\
\hline
\end{tabular}

Here, gene sets indicates the pathway id in wikipathway. Description represents the name of the pathways in which resulted DEPs found. size indicates the total no. of proteins in each pathway. FDR (false discovery rate), for dark blue colour FDR $<0.05$ and for light blue colour FDR $>0.05$. enrichment ratio is the ratio of the obsereved count over expected count by chance.

\section{Figures}

\section{Behavioural test}
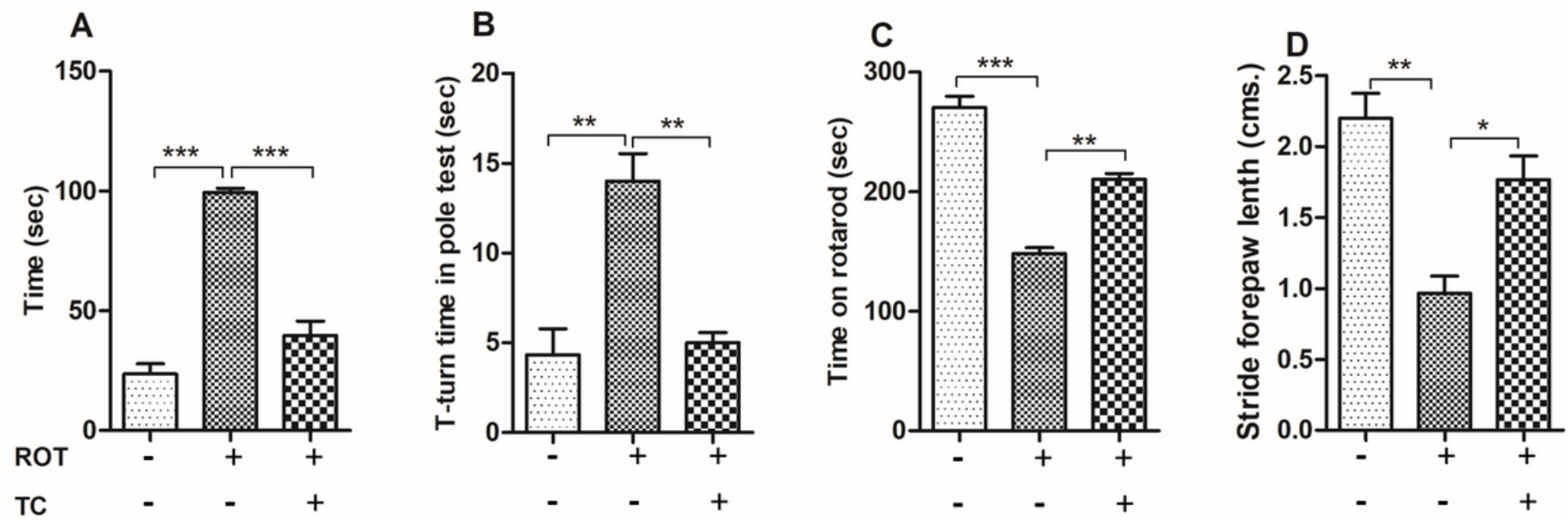


\section{Figure 1}

Neurobehavioral test of ROT- intoxicated mice treated with Tc. (A) Time in Cataleptic test (B) T-turn time in the pole test. (C) Time on the rotarod test (D) Stride forepaw length in Foot print test. Values are represented in the form of mean \pm SEM $(n=8) . * p<0.05, * * p<0.01$, and $* * * p<0.001$.

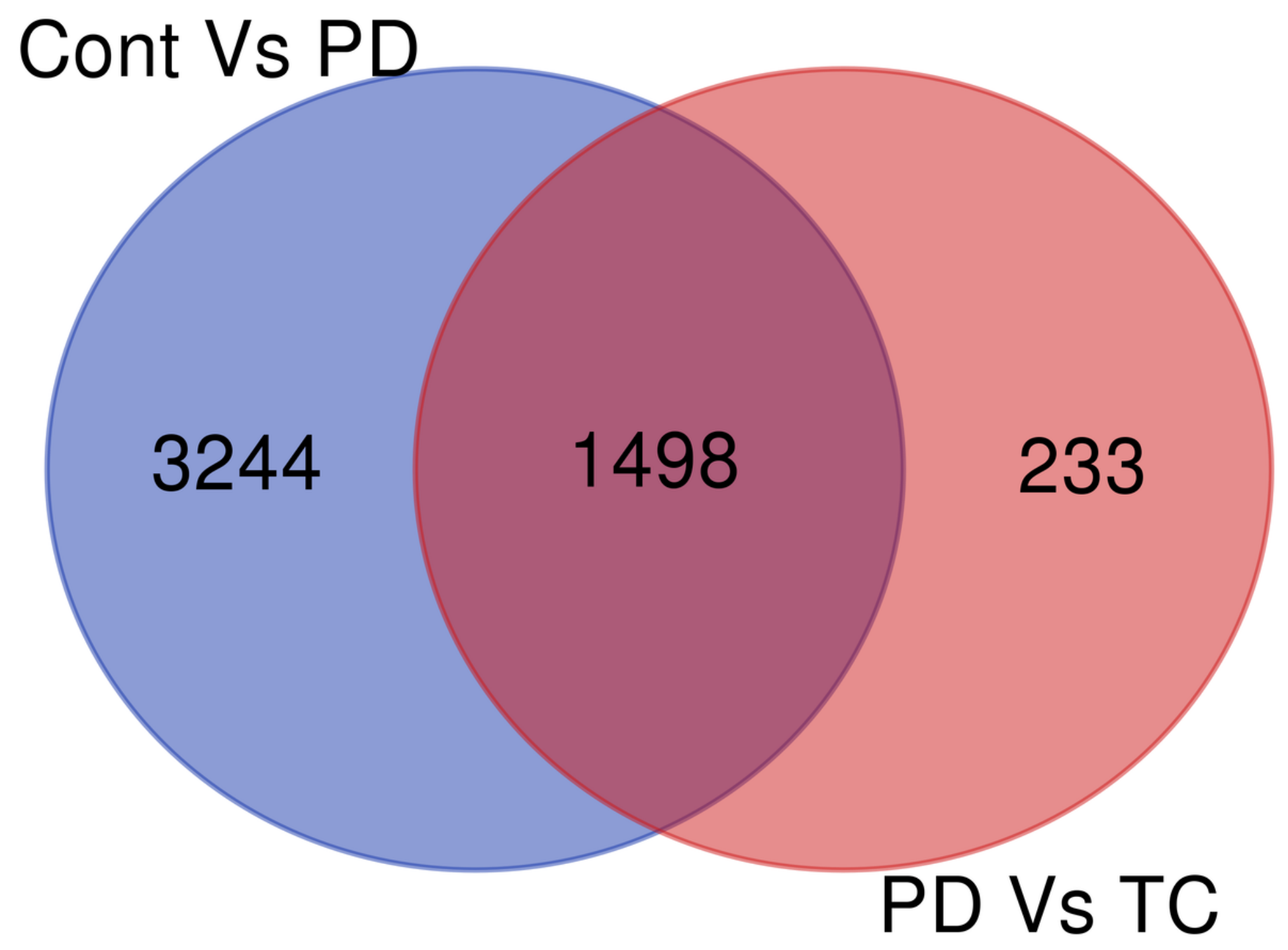

Figure 2

Venn diagram. It reprsent the unique and common proteins was discovered between control vs PD and PD vs Tc. 
a

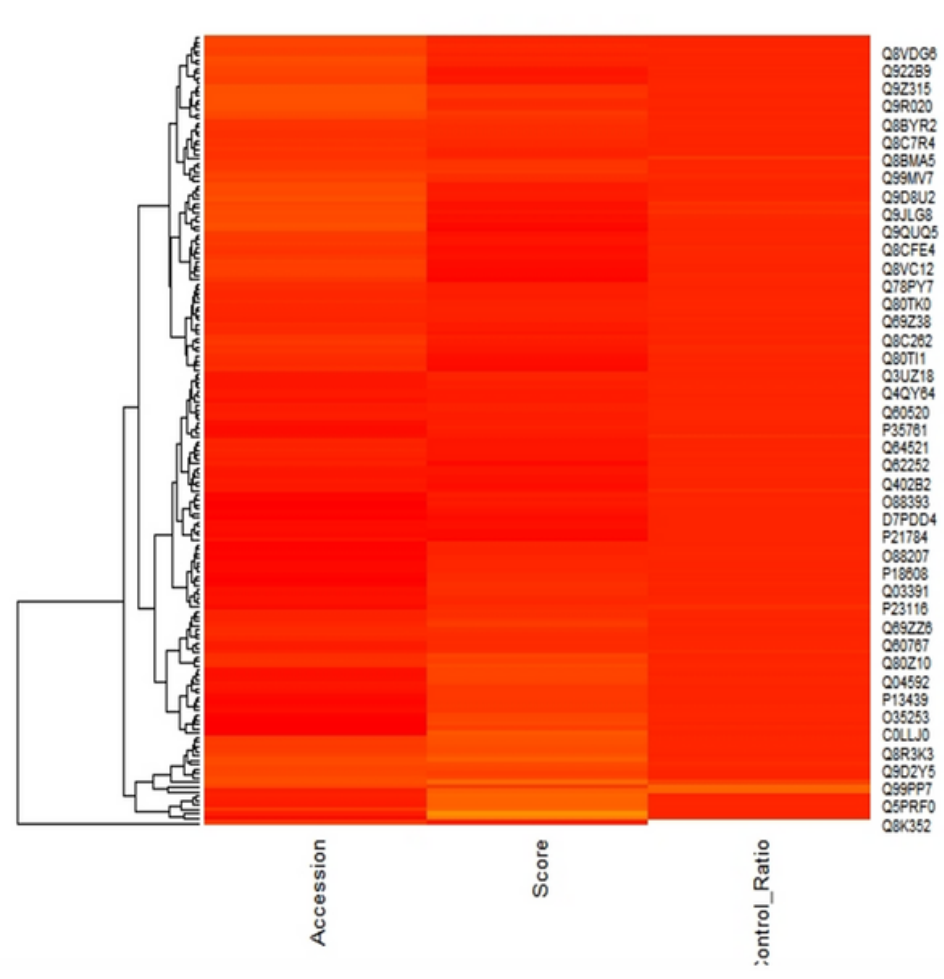

b

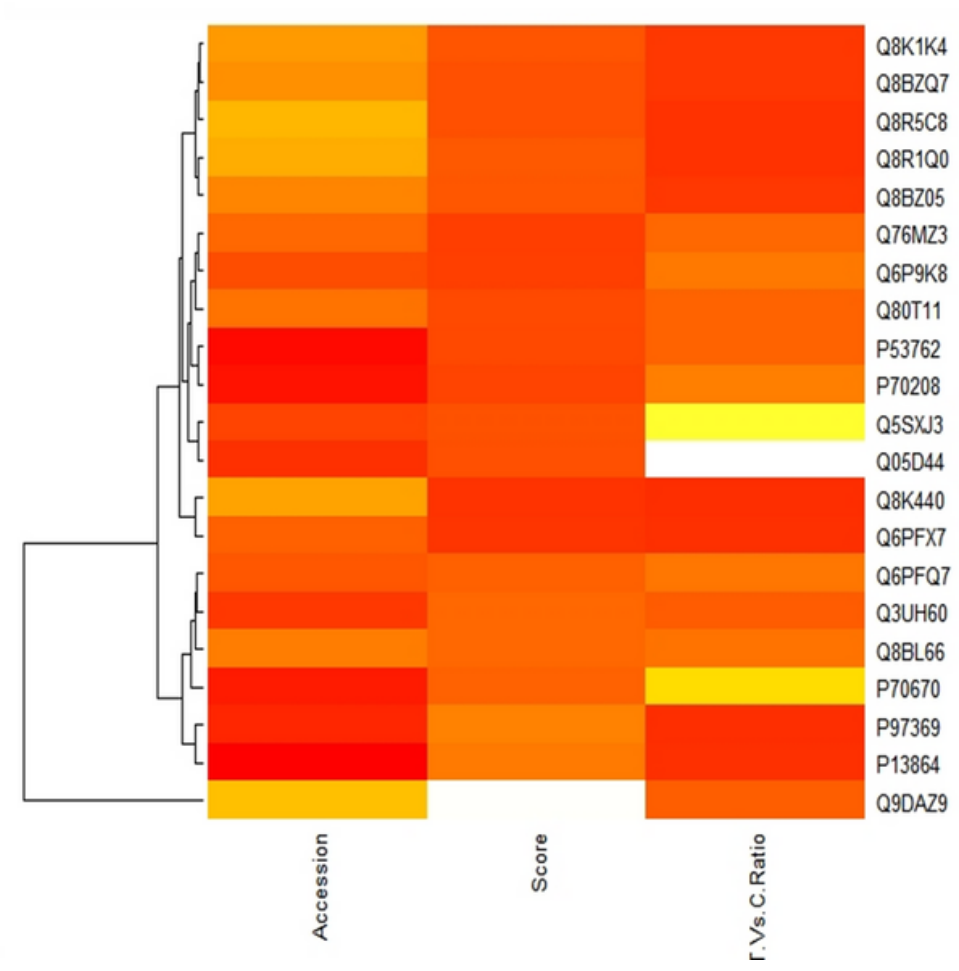

Figure 3

Construction of Heat Map. The heat map represents the expression levels of the resulted proteins. Here, the red coloured regions indicate the high level of protein expression, the orange regions represent the mid value of the protein expression and the yellow regions indicates the low expression of the proteins. Sample are clustered on the basis of relative expression, accession number and $p$-value. 

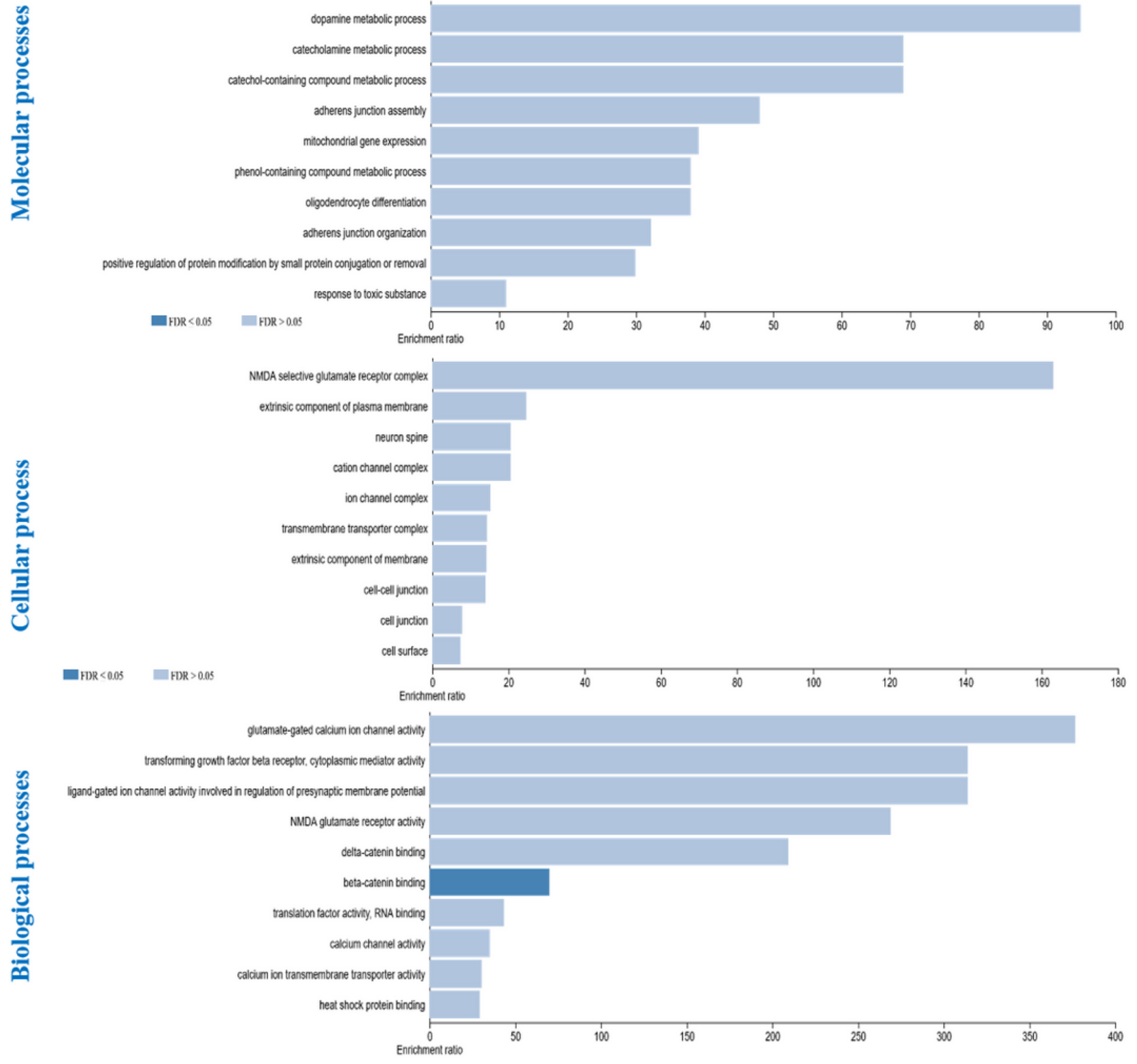

\section{Figure 4}

Gene Ontology Enrichment Analysis was done on the DEPs. A WEB-based tool webgestalt was used tom perform the go analysis which includes three main modules i.e. Biological processes, Molecular function and Cellular component respectively. 

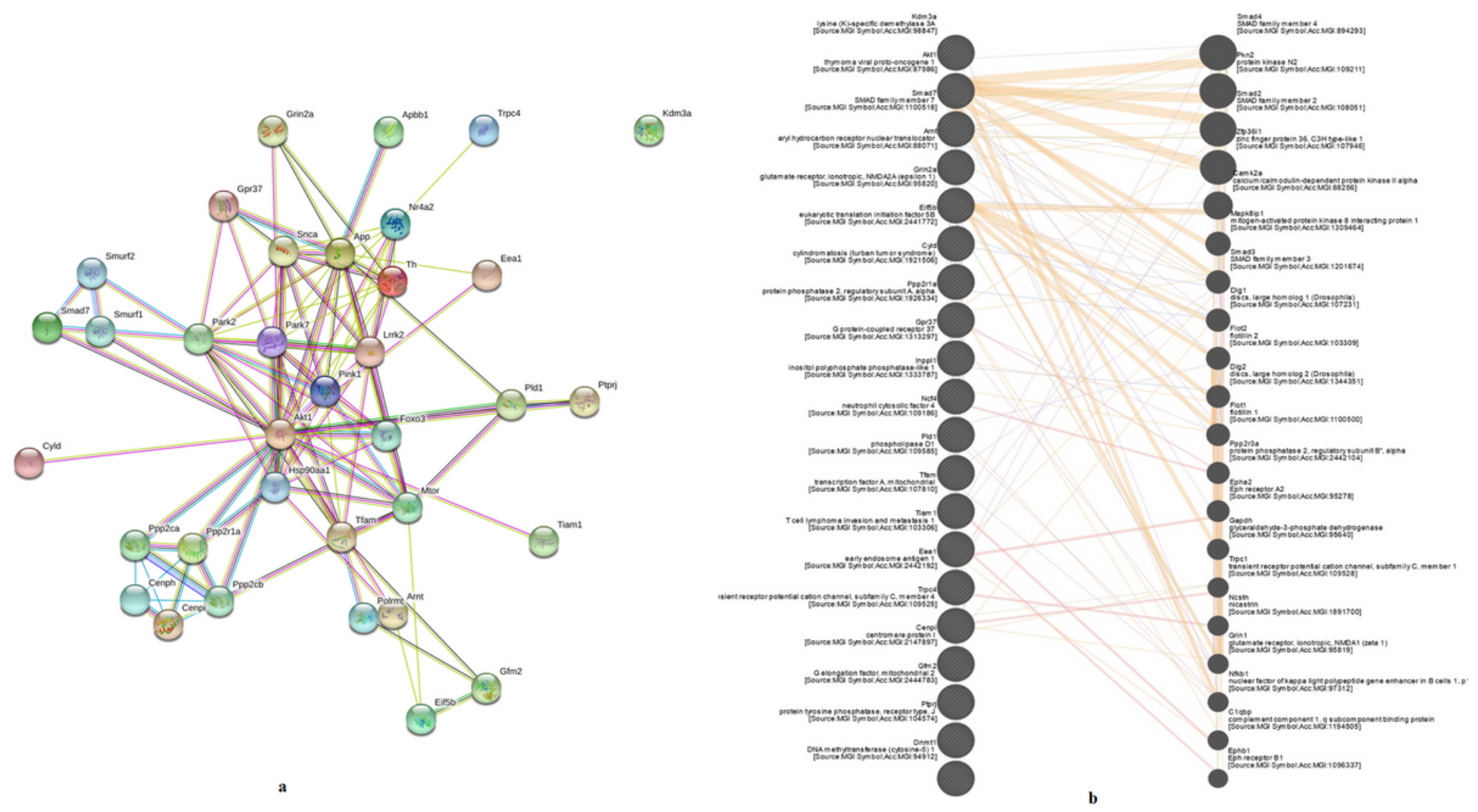

Figure 5

Protein-Protein interaction network construction among the DEPs, along with gene-gene interaction network. (A)PPI network was constructed by databse named string. (B) In gene-gene interaction the nodes with lines on them were our resulted proteins where the nodes with out lines on them were the proteins from the database and it was performed by genemania. In both the network the different coloured edges indicates the different interactions among resulted DEPs. The width of the edge reprents how strong the intraction between the resulted DEPs and among predicted proteins. 

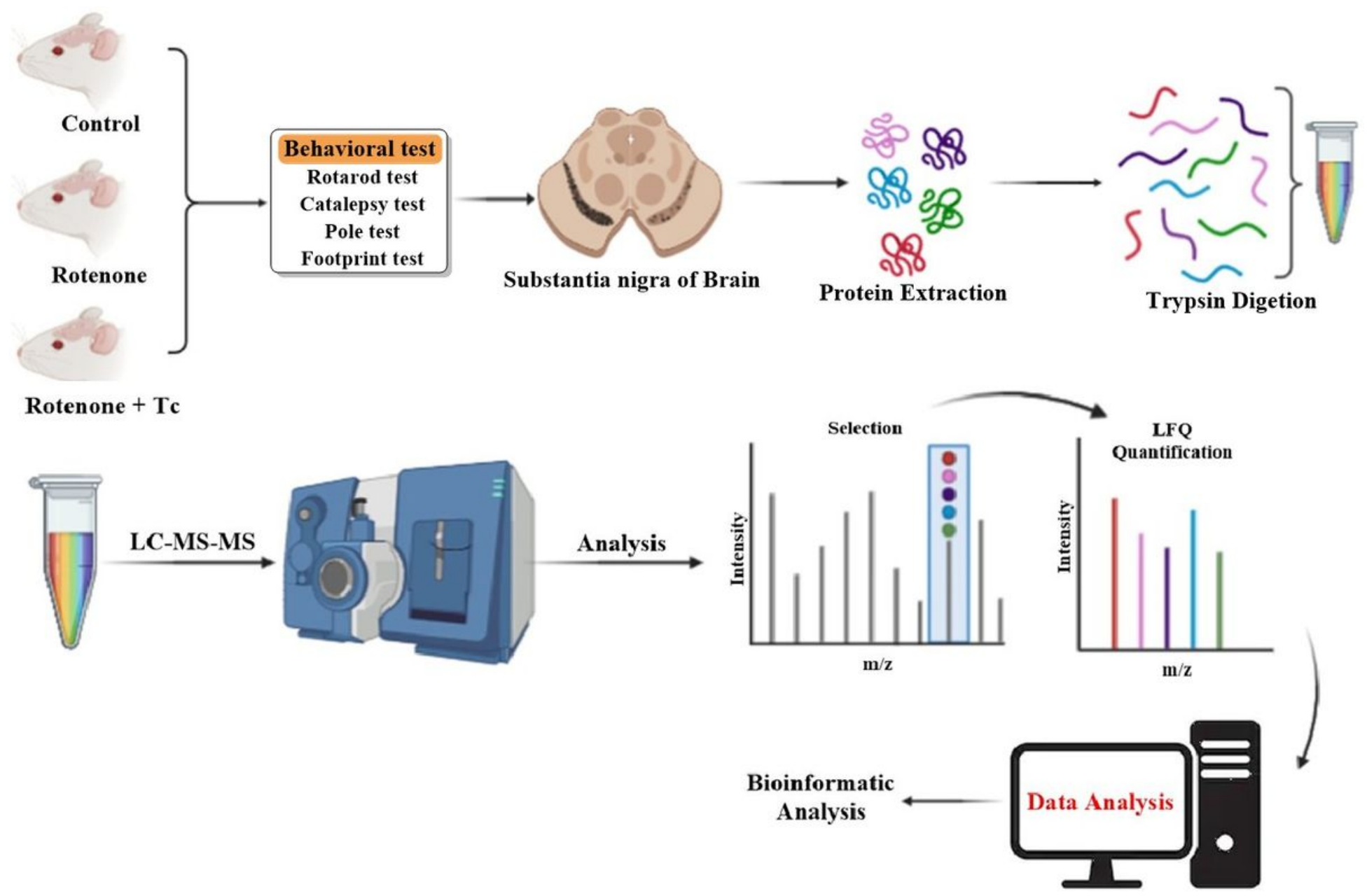

Figure 6

Graphical reprentation of methodology used for LFQ analysis of Control, PD and treatment groups. Proteins were isolate and digested with multiple proteases followed by LC-MS/MS. Each sample were processed in triplicate. 


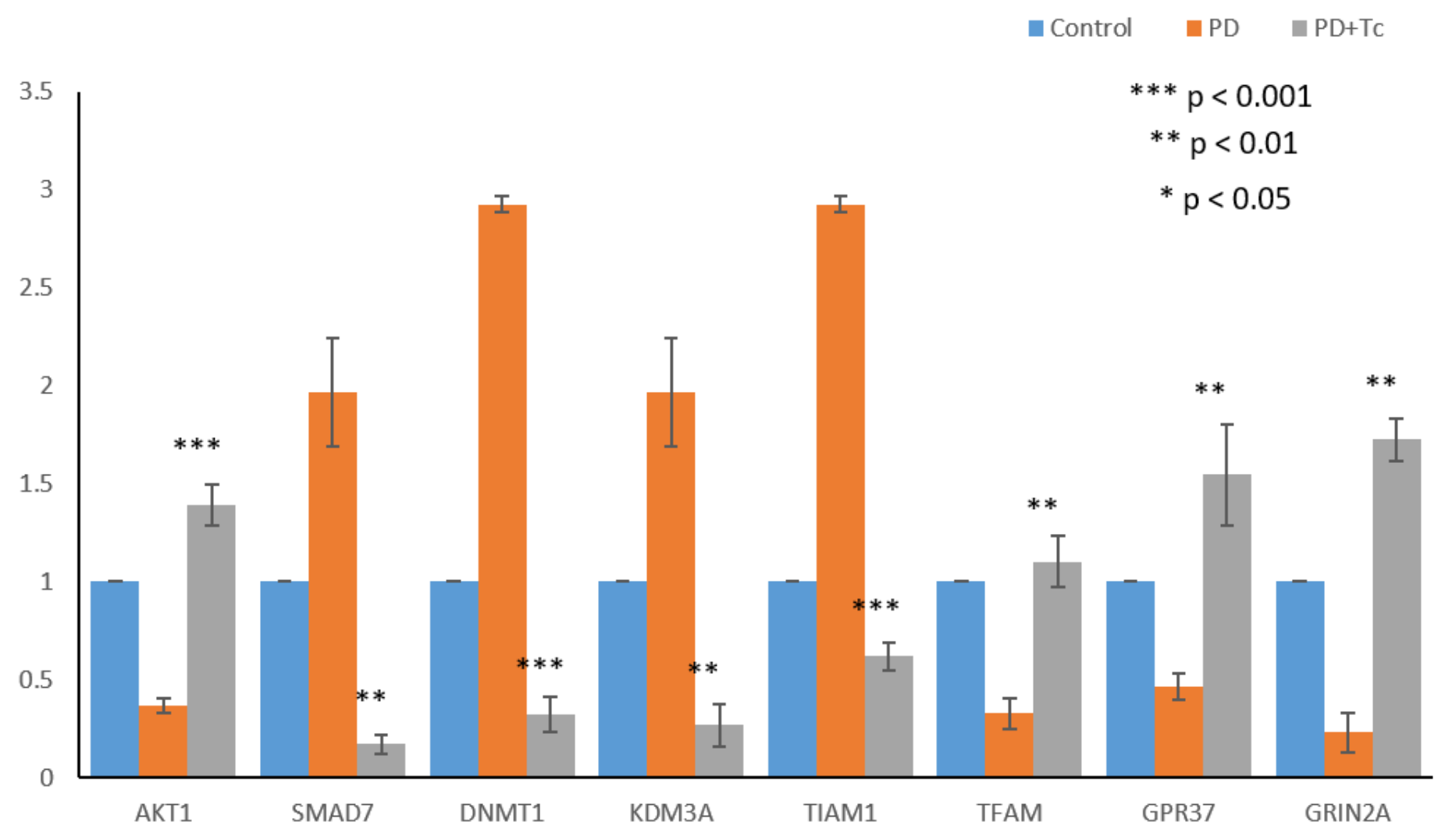

Figure 7

Fold change in gene expression of various genes in ROT-intoxicated and Co-treated mice, in comparison to healthy control. . Value expressed as mean \pm SEM $(n=3)\left(* \star p<0.01\right.$, $\left.{ }^{\star \star *} p<0.001, n=3\right)$. 


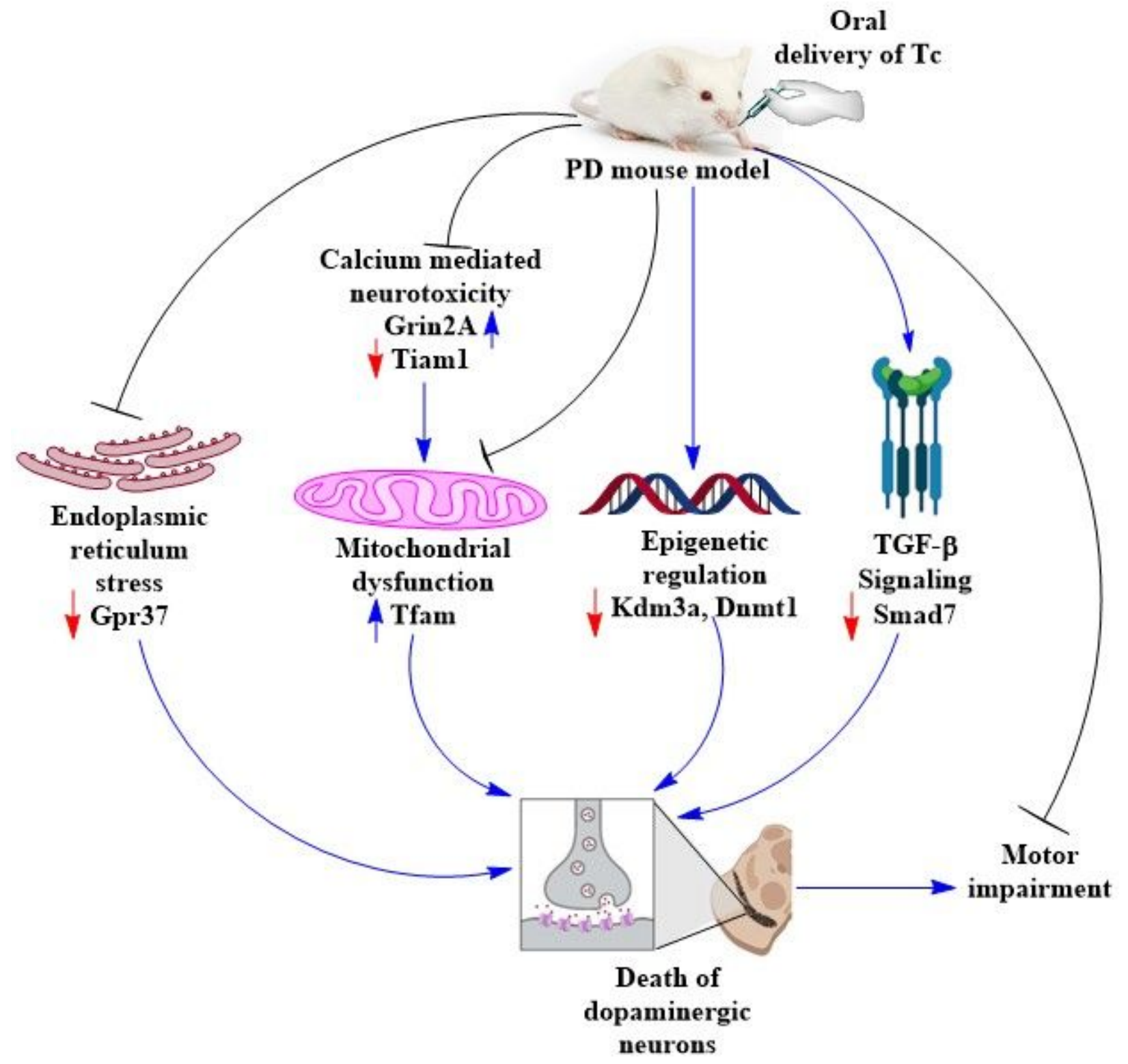

Figure 8

pictorial represent of the pathways found to be involved in PD progression and modulated by Tc treatment in Parkinsonian mice model.

\section{Supplementary Files}

This is a list of supplementary files associated with this preprint. Click to download.

- SM1.xlsx

- SM2.docx 